\title{
Interannual variability of the boreal summer tropical UTLS in observations and CCMVal-2 simulations
}

\author{
Markus Kunze $^{1}$, Peter Braesicke ${ }^{2}$, Ulrike Langematz ${ }^{1}$, and Gabriele Stiller ${ }^{2}$ \\ ${ }^{1}$ Institut für Meteorologie, Freie Universität Berlin, Carl-Heinrich-Becker-Weg 6-10, 12165 Berlin, Germany \\ ${ }^{2}$ Institut für Meteorologie und Klimaforschung, Karlsruher Institut für Technologie, Hermann-von-Helmholtz-Platz 1, \\ 76344 Leopoldshafen, Germany
}

Correspondence to: Markus Kunze (markus.kunze@met.fu-berlin.de)

Received: 8 December 2015 - Published in Atmos. Chem. Phys. Discuss.: 18 January 2016

Revised: 24 June 2016 - Accepted: 27 June 2016 - Published: 15 July 2016

\begin{abstract}
During boreal summer the upper troposphere/lower stratosphere (UTLS) in the Northern Hemisphere shows a distinct maximum in water vapour $\left(\mathrm{H}_{2} \mathrm{O}\right)$ mixing ratios and a coincident minimum in ozone $\left(\mathrm{O}_{3}\right)$ mixing ratios, both confined within the Asian monsoon anticyclone (AMA). This well-known feature has been related to transport processes emerging above the convective systems during the Asian summer monsoon (ASM), further modified by the dynamics of the AMA. We compare the ability of chemistry-climate models (CCMs) to reproduce the climatological characteristics and variability of $\mathrm{H}_{2} \mathrm{O}, \mathrm{O}_{3}$, and temperature in the UTLS during the boreal summer with MIPAS satellite observations and ERA-Interim reanalyses. By using a multiple linear regression model the main driving factors, the strength of the ASM, the quasi-biennial oscillation (QBO), and the El Niño-Southern Oscillation (ENSO), are separated. The regression patterns related to ENSO show a coherent, zonally asymmetric signal for temperatures and $\mathrm{H}_{2} \mathrm{O}$ mixing ratios for ERA-Interim and the CCMs and suggest a weakening of the ASM during ENSO warm events. The QBO modulation of the lower-stratospheric temperature near the Equator is well represented as a zonally symmetric pattern in the CCMs. Changes in $\mathrm{H}_{2} \mathrm{O}$ and $\mathrm{O}_{3}$ mixing ratios are consistent with the $\mathrm{QBO}$-induced temperature and circulation anomalies but less zonally symmetric than the temperature pattern. Regarding the ASM, the results of the regression analysis show for ERA-Interim and the CCMs enhanced $\mathrm{H}_{2} \mathrm{O}$ and reduced $\mathrm{O}_{3}$ mixing ratios within the AMA for stronger ASM seasons. The CCM results can further confirm earlier studies which emphasize the importance of the Tibetan Plateau/southern slope of the
\end{abstract}

Himalayas as the main source region for $\mathrm{H}_{2} \mathrm{O}$ in the AMA. The results suggest that $\mathrm{H}_{2} \mathrm{O}$ is transported towards higher latitudes at the north-eastern edge of the AMA rather than towards low equatorial latitudes to be fed into the tropical pipe.

\section{Introduction}

The future evolution of the abundances of chemically active trace gases has a major influence on the development of stratospheric ozone $\left(\mathrm{O}_{3}\right)$ concentrations. In addition to the chemical composition of the stratosphere, the trace gases also influence the radiation budget of the atmosphere. Identifying the major transport processes responsible for tropospherestratosphere transport is therefore an important issue.

The transport of tracers from the troposphere to the stratosphere is largely realized through the tropical tropopause layer (TTL) (Fueglistaler et al., 2009, and references therein). With respect to vertical transport, the TTL is a transition layer from the convectively dominated tropical troposphere to the tropical stratosphere that is characterized by slow ascent in the upward branch of the wave-driven BrewerDobson circulation. The slow ascent in the TTL is due to small net radiative heating, which is balanced by the adiabatic cooling resulting from ascending motion. The amount of water vapour $\left(\mathrm{H}_{2} \mathrm{O}\right)$ that enters the stratosphere depends on the lowest temperature encountered during ascent, where moist air is freeze dried until the $\mathrm{H}_{2} \mathrm{O}$ mixing ratios are as low as the saturation mixing ratio of the region passed through (Brewer, 1949). In addition to the slow vertical trans- 
port, which takes place in a fast horizontally directed flow (Holton and Gettelman, 2001), there is evidence of direct injections of $\mathrm{H}_{2} \mathrm{O}$ into the stratosphere by convection overshooting the tropopause (e.g. Sherwood and Dessler, 2000) or direct injections of ice particles into the lower stratosphere that evaporate and moisten the lower stratosphere (Corti et al., 2008).

In recent years the off-equatorial Asian summer monsoon (ASM) has also been recognized as a contributor to the transport of trace gases from the troposphere to the stratosphere (Gettelman et al., 2004; Bannister et al., 2004; Fu et al., 2006; Wright et al., 2011; Randel et al., 2010, 2015). Observational and model studies (e.g. Rosenlof et al., 1997; Pan et al., 1997; Gettelman et al., 2004; Randel and Park, 2006; Park et al., 2007; Kunze et al., 2010; Ploeger et al., 2013) have shown that during boreal summer the maximum in $\mathrm{H}_{2} \mathrm{O}$ coincides with a minimum in $\mathrm{O}_{3}$, confined to the Asian monsoon anticyclone (AMA) in the upper troposphere/lower stratosphere (UTLS). The AMA can be explained as a dynamic response to diabatic heating by the underlying convective activity (Gill, 1980). It has been shown that the area of main convective activity, identified by low values of outgoing long-wave radiation (OLR) in the Bay of Bengal (BoB) and its surroundings, is displaced to the south-east of the AMA and the location of the $\mathrm{H}_{2} \mathrm{O}$ maximum at $100 \mathrm{hPa}$ (e.g. Park et al., 2007). As analysed by Park et al. (2009) the convective systems transport tracers from the source region up to $\sim 200 \mathrm{hPa}$. At that altitude, near the level of main convective outflow, the divergent flow further advects the tracers mainly to the south-west and to the north-east towards the North Pacific Ocean. These outflows in the longitudinal direction have been classified as transverse circulations by Yang et al. (1992) and Webster et al. (1998), with the outflow to the north-east identified as part of the Walker circulation and the outflow in the latitudinal direction classified as lateral circulation that is part of the reversed Hadley circulation. In contrast, the role of the orography of the Tibetan Plateau (TP) and heating above the TP in forming the AMA has been studied by Liu et al. (2007) with a simplified general circulation model (GCM). They found heating above the TP to be the predominant forcing of the upper-level anticyclonic flow. However, a study by Boos and Kuang (2010) identified the orography of the TP to be more important than the plateau heating.

In order to analyse the origins and the transport pathways of constituents in the UTLS of the ASM region backward trajectory studies have widely been used (e.g. Jensen and Pfister, 2004; Fueglistaler et al., 2004; James et al., 2008; Kremser et al., 2009; Ploeger et al., 2011; Wright et al., 2011; Bergman et al., 2013). To estimate the relative role of specific regions within the ASM area, four main source regions are usually compared: the BoB and the Indian subcontinent (both regions sometimes combined as MON), the southern slope of the Himalayas (SS), and the TP. Fu et al. (2006) and Wright et al. (2011) identified the regions of the TP and the SS as most important to bypass the lowest cold point and moisten the air within the AMA. This is consistent with Heath and Fuelberg (2014), who used a model system that explicitly resolved convection to show that $90 \%$ of the air parcels influenced by convection within the AMA are connected to the convection over the TP and the SS. They emphasized that, due to the high elevation of the TP, convection does not necessarily have to be particularly strong to reach the AMA. In contrast, Chen et al. (2012) identified the TP and the SS to be only of minor importance as source region for tracers in the tropopause layer, and they highlighted that the region extending from the western Pacific to the South China Sea is most important.

The extratropical lower stratosphere exhibits a strong seasonal cycle in $\mathrm{H}_{2} \mathrm{O}$ mixing ratios, which Ploeger et al. (2013) argued to be almost entirely created by horizontal transport on isentropic levels from low latitudes. They show that filaments of high $\mathrm{H}_{2} \mathrm{O}$ mixing ratios at $390 \mathrm{~K}$, drawn out of the ASM region on the eastern side of the AMA, are responsible for $\mathrm{H}_{2} \mathrm{O}$ transport from low to high latitudes during boreal summer. The potential of this kind of $\mathrm{H}_{2} \mathrm{O}$ transport out of the ASM region for moistening the extratropical lower stratosphere was already investigated by Dethof et al. (1999). Whereas there is agreement about the ASM in moistening the lower stratosphere at higher latitudes, the discussion of the role of the ASM contributing to the moist phase of the stratospheric tropical $\mathrm{H}_{2} \mathrm{O}$ tape-recorder signal is controversial. For example, Wright et al. (2011) found only a minor contribution of the ASM to the mean tropical stratospheric $\mathrm{H}_{2} \mathrm{O}$, while other studies (e.g. Gettelman et al., 2004; Bannister et al., 2004) highlighted the large impact of the ASM on the moist phase of the tropical $\mathrm{H}_{2} \mathrm{O}$ tape recorder. Randel et al. (2010) argued for a direct link between the pollutants produced in the East Asian region and enhanced hydrogen cyanide (HCN) mixing ratios in the tropical lower stratosphere transported upward through the core of the subtropical upper-tropospheric AMA, where high HCN mixing ratios appear to be well confined. Konopka et al. (2009) and Ploeger et al. (2012) identified horizontal isentropic transport from higher latitudes into the tropics, especially during summer when the subtropical transport barrier is weak. According to these studies this in-mixing is an important contributor to the annual cycle of tracers in the TTL.

Superimposed on the climatological $\mathrm{H}_{2} \mathrm{O}$ and $\mathrm{O}_{3}$ concentrations in the UTLS, described so far, is the interannual variability caused by internal modes of variability like El NiñoSouthern Oscillation (ENSO) and the quasi-biennial oscillation (QBO), or the internal variability of the ASM itself. Additional variability arises from external forcing, like the 11year solar cycle, or from sporadic events like volcanic eruptions. These components are not independent of each other, as for example the ASM itself is influenced by ENSO (e.g. Webster and Yang, 1992), the QBO (Giorgetta et al., 1999), or the 11-year solar cycle (van Loon and Meehl, 2012). As shown by Kunze et al. (2010), the strength of the ASM has 
some influence on the observed $\mathrm{H}_{2} \mathrm{O}$ maximum and $\mathrm{O}_{3}$ minimum mixing ratios confined by the AMA, with increasing $\mathrm{H}_{2} \mathrm{O}$ and decreasing $\mathrm{O}_{3}$ mixing ratios during strong ASM seasons. However, a recent study by Randel et al. (2015) suggested that increasing $\mathrm{H}_{2} \mathrm{O}$ mixing ratios within the AMA can also be related to weaker ASM seasons.

The aim of this study is to assess, through a comparison to satellite data, chemistry-climate model (CCM) simulations of the recent past with respect to their ability to capture the $\mathrm{H}_{2} \mathrm{O}$ and $\mathrm{O}_{3}$ climatological distribution in the UTLS during the ASM. In addition, the ASM related mean circulation and temperature patterns will be compared with a reanalysis data set. Further, we want to identify the relative importance of the ASM, in comparison to ENSO and the QBO, in modulating the $\mathrm{H}_{2} \mathrm{O}$ and $\mathrm{O}_{3}$ mixing ratios in the UTLS. The paper is organized as follows: after introducing the data (Sect. 2) and methods (Sect. 3), the climatological state of the horizontal circulation and the $\mathrm{H}_{2} \mathrm{O}$ and $\mathrm{O}_{3}$ mixing ratios of the CCMs in the UTLS are compared with observations and reanalyses during July/August (JA) in Sect. 4. The interannual variability of the temperature and the $\mathrm{H}_{2} \mathrm{O}$ and $\mathrm{O}_{3}$ concentrations is then investigated in Sect. 5, followed by a summary and the conclusions in Sect. 6.

\section{Models and data}

We use data from CCMs collected for Phase II of the Chemistry-Climate Model Validation Activity (CCMValII) for Stratospheric Processes and their Role in Climate (SPARC). We focus on the so-called REF-B1 simulations of the recent past covering the period from 1960 to 2004. The SPARC Report No. 5 "Chemistry-Climate Model Validation" (SPARC CCMVal, 2010) gives a comprehensive overview of the details of the CCMs used in this study; therefore only the main features are summarized in Sect. 2.1.

\subsection{Chemistry-climate model data}

Here, we use monthly-mean data of temperature, zonal and meridional wind, vertical velocity, $\mathrm{H}_{2} \mathrm{O}, \mathrm{O}_{3}$, and long-wave and short-wave heating rates, varying in longitude, latitude, pressure, and time. Only a subset of the CCMs, participating in the CCMVal-II activity, has provided all required data to the CCMVal archive, which limits the analyses to the CCMs listed in Table 1. Most CCMs have their upper boundary in the upper mesosphere or lower thermosphere; E39CA is the only model with an upper boundary in the middle stratosphere at $10 \mathrm{hPa}$. The vertical resolution in the UTLS region (300-100 hPa) ranges from 5 (EMAC-FUB and SOCOL) to 15 (E39CA) levels.

\section{Model runs}

The specifications of the CCMVal REF-B1 scenario were designed to produce best-estimate model simulations of the recent past from 1960 to 2006 (Eyring et al., 2008). They define a transient set-up that includes all anthropogenic and natural forcings, with greenhouse gases (GHGs) according to IPCC (2001) (updated with NOAA observations to 2006), ozone-depleting substances according to WMO (2007), and prescribed monthly varying sea surface temperatures (SSTs) and sea ice concentrations from the global HadISST1 data set (Rayner et al., 2003). To account for the effect of the major volcanic eruptions on the temperatures in the stratosphere and troposphere, additional heating rates for the stratosphere and cooling of the surface have been prescribed or calculated from an aerosol data set, where possible. The effect of volcanic aerosol on heterogeneous chemistry is taken into account by prescribing a surface area density data set. The solar variability of the 11-year solar cycle and the 27-day solar rotational period is included in some simulations by spectrally resolved solar irradiances on a daily basis (Lean et al., 2005). The QBO is not included in all CCMs (see Table 1). In a subset of CCMs it is nudged, or it develops internally (UMUKCA-UCAM, EMAC) in CCMs with sufficiently high vertical resolution and an adequate gravity-wave parametrization. EMAC has an internally generated QBO and weak nudging is applied to force the model towards the observed timing of the QBO phase.

\subsection{Reanalyses and satellite data}

The European Centre for Medium-range Weather Forecasts (ECMWF) interim reanalyses (ERA-Interim) data from 1979 to 2014 (Dee et al., 2011) are used in this study to assess the monsoonal wind structure, the velocity potential, and the stream function. The ERA-Interim $\mathrm{H}_{2} \mathrm{O}$ and $\mathrm{O}_{3}$ data are used in regression analyses, when longer time series covering a large part of the modelled time period are necessary. The period used for the ERA-Interim data does not exactly match the period of the REF-B1 simulations of the CCMs, but due to the overlapping period from 1979 to 2004, covering nearly $60 \%$ of the REF-B1 period, a comparison with ERA-Interim is still useful. The quality of the ERA-Interim $\mathrm{O}_{3}$ data has been assessed by Dragani (2011), showing a better quality compared to the previous ERA-40 reanalysis (Uppala et al., 2005). However, within the UTLS the quality of the ERAInterim $\mathrm{O}_{3}$ data might still be limited, as it is mostly constrained by total column ozone in this region. In contrast, due to the relatively long lifetime of $\mathrm{O}_{3}$ in the UTLS, it can be used as a dynamic tracer.

As observational reference for the climatological JA water vapour and ozone mixing ratios on the 380 and $370 \mathrm{~K}$ isentropic level we use the Michelson Interferometer for Passive Atmospheric Sounding (MIPAS) satellite data of $\mathrm{H}_{2} \mathrm{O}$ (Milz et al., 2009; von Clarmann et al., 2009) and $\mathrm{O}_{3}$ (Steck et al., 2007; von Clarmann et al., 2009). MIPAS measures $\mathrm{H}_{2} \mathrm{O}$ and $\mathrm{O}_{3}$, among numerous other species, as a limb emission midinfrared sounder with high spectral resolution from a sunsynchronous polar orbit at about $800 \mathrm{~km}$ altitude. It covers 
Table 1. Main characteristics and specifications of the chemistry-climate models used. More comprehensive information can be found in Morgenstern et al. (2010).

\begin{tabular}{llrrl}
\hline CCM & Horiz. res. & Levels/upp. bound. & Levels: $300-100 \mathrm{hPa}$ & QBO \\
\hline CCSRNIES & T42 & $34 / 0.012 \mathrm{hPa}$ & 6 & nudged \\
CMAM & T31 & $71 / 0.00081 \mathrm{hPa}$ & 7 & no \\
CNRM-ACM & T42/T21 & $60 / 0.07 \mathrm{hPa}$ & 8 & no \\
E39CA & T30 & $39 / 10 \mathrm{hPa}$ & 15 & nudged \\
EMAC & T42 & $90 / 0.01 \mathrm{hPa}$ & 12 & weakly nudged \\
EMAC-FUB & $\mathrm{T} 42$ & $39 / 0.01 \mathrm{hPa}$ & 5 & nudged \\
GEOSCCM & $2^{\circ} \times 2.5^{\circ}$ & $72 / 0.015 \mathrm{hPa}$ & 7 & no \\
SOCOL & $\mathrm{T} 30$ & $39 / 0.01 \mathrm{hPa}$ & 5 & nudged \\
UMUKCA-UCAM & $2.5^{\circ} \times 3.75^{\circ}$ & $60 / 84 \mathrm{~km}$ & 7 & internal \\
WACCM & $1.9^{\circ} \times 2.5^{\circ}$ & $66 / 5.96 \times 10^{-6} \mathrm{hPa}$ & 7 & nudged \\
\hline
\end{tabular}

the atmosphere from cloud top to $70 \mathrm{~km}$ by scanning from top to bottom with a step width of $1.5 \mathrm{~km}$ (UTLS, since 2005) to $8 \mathrm{~km}$ (mesosphere, before 2005). Data are recorded every $400 \mathrm{~km}$ along the orbit, with 14.4 orbits per day, providing one profile per day roughly every $4^{\circ}$ latitude and $12.5^{\circ}$ longitude. Cloud contamination reduces the achievable coverage.

The atmospheric distributions of $\mathrm{H}_{2} \mathrm{O}$ and $\mathrm{O}_{3}$ used in this study were derived using the MIPAS level-2 data processor at the Institut für Meteorologie und Klimaforschung/Instituto de Astrofísica de Andalucía (von Clarmann et al., 2003) from observations of 57 days overall during July and August 2003 and 2005-2009 (6 years). The precision, accuracy, and vertical resolution of single profiles in the relevant altitude range of $\mathrm{H}_{2} \mathrm{O}\left(\mathrm{O}_{3}\right)$ is $5-6 \%, 8-17 \%$, and $2.3-3.3 \mathrm{~km}(3.8-12.6 \%$, 9.6-17.0\%, 2.4-2.9 km) respectively (von Clarmann et al., 2009).

NOAA interpolated monthly average OLR data (Liebmann and Smith, 1996) from 1975 to 2013 are used as a proxy for deep convection.

\section{Methods}

\subsection{Climatology of the AMA}

We derive climatologies to compare the average impact of the ASM on the upper-tropospheric circulation, temperatures, $\mathrm{H}_{2} \mathrm{O}$, and $\mathrm{O}_{3}$ mixing ratios of multi-model averages (MMOD) with ERA-Interim reanalyses and MIPAS satellite observations. By nature, the MMOD will level out the occasionally large differences among individual CCMs in comparison to the reanalysis and satellite observation. Characteristic quantities derived as box averages, or extreme values within a certain area related to the AMA, are derived for the individual models to assess the model spread of the CCMs, in comparison to the MMOD and the observational reference. The spread in statistics for individual CCMs is an indication of the robustness of the MMOD.

\subsection{Interannual variability of the AMA}

The variability of the temperatures and the $\mathrm{H}_{2} \mathrm{O}$ and $\mathrm{O}_{3}$ mixing ratios is analysed with a multiple linear regression (MLR) model to estimate the relative importance of the ASM circulation, ENSO, and the QBO for these quantities in the UTLS.

\subsubsection{Separating tropical circulations}

To quantify the interannual variability of the ASM circulation, a monsoon circulation index is calculated as described in Tanaka et al. (2004). The method is based on the separation of the horizontal flow in the upper troposphere. According to the Helmholtz theorem, the horizontal flow can be separated into a rotational, non-divergent component $\left(v_{\mathrm{h} / \mathrm{r}}\right)$ and a divergent, irrotational component $\left(\boldsymbol{v}_{\mathrm{h} / \mathrm{d}}\right): \boldsymbol{v}_{\mathrm{h}}=\boldsymbol{v}_{\mathrm{h} / \mathrm{r}}+\boldsymbol{v}_{\mathrm{h} / \mathrm{d}}$, with $\nabla \cdot \boldsymbol{v}_{\mathrm{h} / \mathrm{r}}=0$ and $\nabla \times \boldsymbol{v}_{\mathrm{h} / \mathrm{d}}=0$. This allows us to express the horizontal flow by a combination of stream function $\psi$ and velocity potential $\chi$ in the following way: $\boldsymbol{v}_{\mathrm{h}}=\boldsymbol{k} \times \nabla \psi+\nabla \chi$, with $\boldsymbol{k}$ representing the vertical unit vector.

Tanaka et al. (2004) suggested a method to separate the tightly coupled tropical circulations (Hadley, Walker, and monsoon circulation) by separating the velocity potential $\chi$.

$\chi(t, x, y)=[\chi(t, y)]+\bar{\chi}^{*}(x, y)+\chi^{* \prime}(t, x, y)$,

where in a first step $\chi(t, x, y)$ is separated into the zonal mean $[\chi(t, y)]$, supposed to represent the Hadley circulation, and the eddy component $\chi^{*}(t, x, y)$. The eddy component can be further separated into a time mean component $\bar{\chi}^{*}(x, y)$, considered to represent the main characteristics of the Walker circulation, and a transient component $\chi^{* \prime}(t, x, y)$, considered to represent a large fraction of the ASM circulation. As stated by Tanaka et al. (2004) all three tropical circulations are tightly coupled to each other and the separation of $\chi$ might therefore be limited. Nevertheless, $\chi^{* \prime}(t, x, y)$ reflects the seasonal change of $\chi$ and is therefore influenced by the ASM circulation.

During the ASM season, the strength of $\chi^{* \prime}(t, x, y)$ can directly be related to the intensity of the ASM, with strong 
upper-tropospheric divergent flow where the most intense convective systems are located. As focus is on the influence of the ASM on the UTLS, we chose the velocity potential at $150 \mathrm{hPa}$ to derive an index for the monsoon circulation (MIDX) close to the lower stratosphere. The MIDX is defined as the maximum in monthly-mean $\chi^{* \prime}(t, x, y)$ located over Southeast Asia from May to September and the minimum over the same area during the remainder of each year, as $\chi^{* \prime}(t, x, y)$ changes its sign in the respective region for the period from October to April. Due to this definition the MIDX changes from positive values during May-September to negative values during October-April, when the uppertropospheric flow over Southeast Asia is convergent. A timevarying Walker circulation index (WIDX) is produced as the time mean of the eddy component of the velocity potential $\bar{\chi}^{*}(x, y)$, using the running mean of 12 individual months. The values of the WIDX are defined as the maximum in monthly-mean $\bar{\chi}^{*}(x, y)$ over the western Pacific. As all CCMs prescribe SSTs of the HadISST1 data set, they react in a similar way with respect to the Walker circulation. During ENSO warm events the Walker circulation weakens, which is reflected in a decreasing WIDX (not shown).

\subsubsection{Multiple linear regression model}

To identify the temperature and trace gas changes of the lowermost stratosphere associated with the ASM circulation, ENSO, and the phase of the QBO we use a MLR model, as described in SPARC CCMVal (2010). The following basis functions are applied: a constant offset, a linear trend, the QBO, the MIDX, the Niño3.4 index, the $10.7 \mathrm{~cm}$ solar flux, and basis functions for three major volcanic eruptions (Agung, El Chichón, and Pinatubo), which are realized by using an idealized function with a rapid increase and an exponential decay (Bodeker et al., 1998). The time series of the MIDX are calculated separately for each CCM and the ERAInterim data according to Tanaka et al. (2004), as described in Sect. 3.2.1. The QBO basis function consists of the time series of the zonal mean zonal wind at $50 \mathrm{hPa}$ averaged over the two innermost tropical latitudes $\left(1.4^{\circ} \mathrm{S}-1.4^{\circ} \mathrm{N}\right)$, derived for each individual CCM simulation and the ERA-Interim data. The regression model contains, in addition, an orthogonal version of the $50 \mathrm{hPa}$ QBO to account for the fact that within the vertical range of the QBO two distinct phases are present. The Niño3.4 index is calculated as an area-averaged, standardized anomaly of the HadISST1 SST for the Niño3.4 region $170-120^{\circ} \mathrm{W}, 5^{\circ} \mathrm{S}-5^{\circ} \mathrm{N}$. An alternative ENSO index is derived with the WIDX (see Sect. 3.2.1). Because the WIDX is strongly correlated with the Niño3.4 index for the ERAInterim data $(r=0.7)$, only the Niño3.4 index is included in the MLR. The regression model is applied to time series of $n \mathrm{JA}$ averages. The trend and the long-term average are removed for the basis functions $\mathrm{QBO}(t)$, QBO_orthog $(t)$, $\operatorname{MIDX}(t), \mathrm{N} 34(t)$, and $\operatorname{solar}(t)$.

$$
\begin{aligned}
y(t)= & \beta_{\text {offs offset }+\beta_{\text {tr }} \text { trend }(t)+} \\
& \beta_{\text {qbo }} \mathrm{QBO}(t)+\beta_{\text {qbo_or }} \mathrm{QBO} \_ \text {orthog }(t)+ \\
& \beta_{\text {midx }} \operatorname{MIDX}(t)+\beta_{\mathrm{n} 34} \mathrm{~N} 34(t)+\beta_{\text {sfl }} \operatorname{solar}(t)+ \\
& \beta_{\text {vol }} \operatorname{Volcano}(t)+\varepsilon(t), \quad t=1, n
\end{aligned}
$$

The regression Eq. (2) models the time series of a quantity $y(t)$ by linearly fitting the time series of the basis functions to it by means of least squares estimates, resulting in the fit parameters $\beta_{j}$ and a residual $\varepsilon(t)$. Results of the MLR are discussed in Sect. 5 for the fit parameters $\beta_{\mathrm{midx}}, \beta_{\mathrm{n} 34}$, and $\beta_{\mathrm{qbo}}$, which are multiplied by a factor of $1.0,2.5$, and 25.0 respectively to account for a typical amplitude of the proxy time series shown in Fig. 1. The residuals are tested for autocorrelations with a second-order autoregressive model after the regression model has run for a first time. The autoregressive parameters are then used to transform the model according to Tiao et al. (1990). The statistical significance of the estimated fit parameters is tested with a two-tailed Student $t$ test of the null hypothesis $H_{0}: \beta_{j}=0$ with the alternative hypothesis $H_{1}: \beta_{j} \neq 0$. The regression parameters of the individual CCMs are averaged to get a combined response of all CCMs as a multi-model average. To decide about the significance of the combined regression parameters, the weighted $Z$ test (see Whitlock, 2005, and references therein) is used, which combines the $p$ values from the MLR of the individual CCMs.

As a measure of the overall performance of the MLR model we use the adjusted coefficient of determination $\left(R_{\text {Adj }}^{2}\right.$. In large regions of an individual isentropic level, $R_{\text {Adj }}^{2}$ is higher than 0.9, implying that, in large regions, less than $10 \%$ of the total variance is not accounted for by the MLR basis functions and therefore described by the residuals. This overall result is somewhat different among the variables and also varies among the CCMs. Comparison of the MLR performance for ERA-Interim with the results for individual CCMs shows a better performance of the MLR for ERAInterim.

\section{The climatological state of the Asian summer monsoon during July and August}

The diabatic heating associated with the convective systems of the ASM causes a divergent outflow in the UTLS and eventually, as a large-scale organized response, the anticyclone (e.g. Garny and Randel, 2013). Liu et al. (2007) highlighted the role of diabatic heating over the TB in generating a minimum in potential vorticity, coincident with the AMA. The AMA has been recognized to influence the transport pathways of various trace gases (e.g. $\mathrm{CO}, \mathrm{CH}_{4}, \mathrm{H}_{2} \mathrm{O}$, $\mathrm{HCN}$ ), entering the stratosphere in the tropical UTLS (Fu et al., 2006; Randel et al., 2010; Wright et al., 2011). As pointed out by Goswami et al. (1999), the northward migra- 


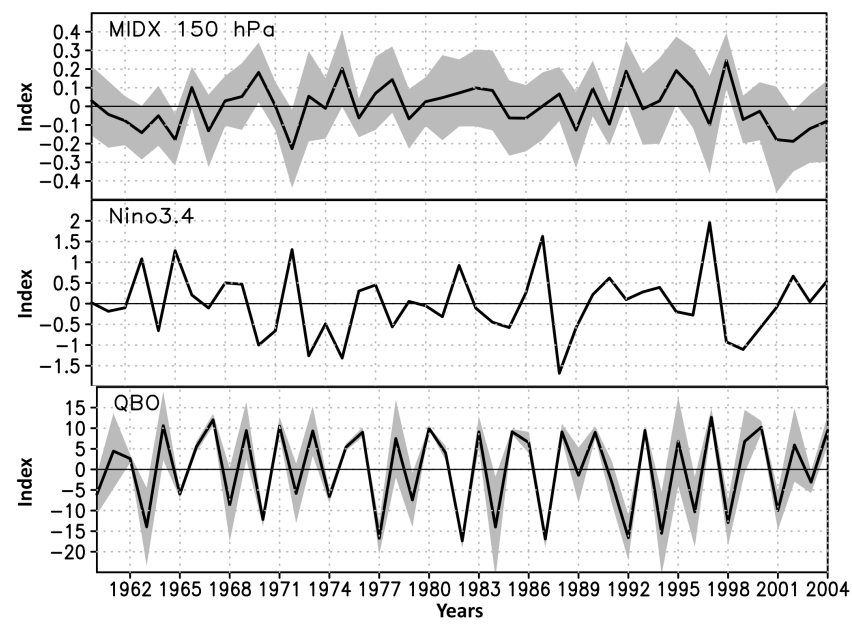

Figure 1. Time series of JA averaged basis functions for the period 1960-2004. Top: index for the monsoon circulation (MIDX) at $150 \mathrm{hPa}$; middle: Niño3.4 index derived from the HadISST1 data set; bottom: zonal mean zonal wind at $50 \mathrm{hPa}$ near the Equator used as a QBO index. The black lines indicate the multi-model mean of the individual time series used for each CCM. Grey shadings indicate 1 standard deviation of the multi-model mean statistics.

tion of strong convective activity during the ASM leads to a regional reversal of the Hadley circulation, with ascent near $20^{\circ} \mathrm{N}$ and descent near the Equator. This is partly, on the eastern flank of the AMA, a manifestation of the strong anticyclonic circulation. In this section the climatological features of the ASM in the CCMs are assessed by comparing the MMOD of their JA average circulation and $\mathrm{H}_{2} \mathrm{O}$ and $\mathrm{O}_{3}$ mixing ratios in the UTLS with ERA-Interim and MIPAS data.

\subsection{The monsoon anticyclone}

The divergence-free part of the horizontal flow is described with the stream function $\psi$ (Sect. 3.2.1). Figure 2 (top) shows that during the mature phase of the ASM the horizontal flow in the UTLS over southern Asia is dominated by an anticyclonic $\psi$, extending from $40^{\circ} \mathrm{W}$ to $160^{\circ} \mathrm{E}$ in the longitudinal and from the Equator to $50^{\circ} \mathrm{N}$ in the latitudinal direction. A second anticyclone exists over North America, related to the North American monsoon. The large values of the cyclonic $\psi$ in the Southern Hemisphere (more than $350 \times 10^{5} \mathrm{~m}^{2} \mathrm{~s}^{-1}$ ) are associated with the polar vortex. The bar chart on the right of Fig. 2 (top) shows the maximum climatological JA $\psi$ for each model within the region, indicated by the black rectangle in Fig. 2 (top). The CCMs show a large spread in their maximum $\psi$ values. Four CCMs strongly underestimate the ERA-Interim $\psi$, leading to a weaker MMOD $\psi$ than in ERA-Interim. As explained, the divergent part of the upper-tropospheric circulation can be described by the velocity potential $\chi$ (Fig. 2, bottom). During JA $\chi$ has the largest positive values centred near $15^{\circ} \mathrm{N}$ in the western Pacific. The stream lines in Fig. 2 (bottom) show the divergent horizontal flow, directed from the maximum $\chi$ towards the minimum, extending from the gulf of Guinea to southern Africa. The positive peak values in $\chi$ are thought to be related to regions of upwelling, coinciding with the outflow of the strongest divergent winds, while the negative peaks coincide with convergence. There is quite good agreement between the ERAInterim data and the MMOD in the location and strength of the up- and downwelling, and the maxima of the individual CCMs in the region of upwelling, indicated by the bar chart on the left side of Fig. 2 (bottom), also have only relatively small deviations from the MMOD compared to the respective deviations of $\psi$ from the MMOD.

\subsection{Mean temperatures, water vapour, and ozone mixing ratios in the UTLS}

MIPAS $\mathrm{H}_{2} \mathrm{O}$ mixing ratios on isentropic levels show large values confined to the centre of the AMA at 360 and $370 \mathrm{~K}$ (less pronounced). At $380 \mathrm{~K}$ enhanced $\mathrm{H}_{2} \mathrm{O}$ mixing ratios spread out to the north-west and east of the AMA (Fig. 3). With increasing height, dehydration reduces the MIPAS peak values of the $\mathrm{H}_{2} \mathrm{O}$ mixing ratios in the ASM region from 48 $(360 \mathrm{~K})$ to $7 \mathrm{ppmv}(380 \mathrm{~K})$ (dashed line in the bar chart in Fig. 3). The low values of the observed outgoing long-wave radiation $\left(<205 \mathrm{~W} \mathrm{~m}^{-2}\right)$, as indicated by the grey shading, identify the $\mathrm{BoB}$ and the western coast of Myanmar to be the region of the strongest convection during JA. The $\mathrm{H}_{2} \mathrm{O}$ maximum at $360 \mathrm{~K}$ is located north-west of the region with strongest convection, and at higher levels ( 370 and $380 \mathrm{~K}$ ) the maximum is even farther away from its supposed source region.

The CCMs show on average a similar behaviour with enhanced $\mathrm{H}_{2} \mathrm{O}$ mixing ratios within the AMA, although the maxima are much higher for most CCMs and tend to spread out more to the north-east. As indicated by the bar charts in Figs. 3 and 4, high $\mathrm{H}_{2} \mathrm{O}$ mixing ratios among the CCMs can often be found where the temperatures are higher than average. The individual CCMs show large deviations in $\mathrm{H}_{2} \mathrm{O}$ extrema from the MMOD in the ASM region, largest at $360 \mathrm{~K}$ and less pronounced at higher levels. Enhanced $\mathrm{H}_{2} \mathrm{O}$ mixing ratios seem to be transported to higher latitudes, as can be seen from the MMOD of the CCMs. This is also described by Ploeger et al. (2013) as a result of filaments of enhanced $\mathrm{H}_{2} \mathrm{O}$ mixing ratios that are drawn out of the anticyclone. However, this is not confirmed by the MIPAS data, which show lower $\mathrm{H}_{2} \mathrm{O}$ mixing ratios northward of $45^{\circ} \mathrm{N}$. The high MMOD $\mathrm{H}_{2} \mathrm{O}$ mixing ratios at high northern latitudes are to a certain degree caused by CCMs (EMAC-FUB and SOCOL) overestimating the $\mathrm{H}_{2} \mathrm{O}$ mixing ratios in the lowermost stratosphere, probably due to their coarse vertical resolution. The MMOD of the CCMs shows strong coherence between the northern hemispheric temperature structures at 370 and $380 \mathrm{~K}$ (Fig. 4) and the corresponding $\mathrm{H}_{2} \mathrm{O}$ mixing ratio fields, with the exception of the ASM and the 


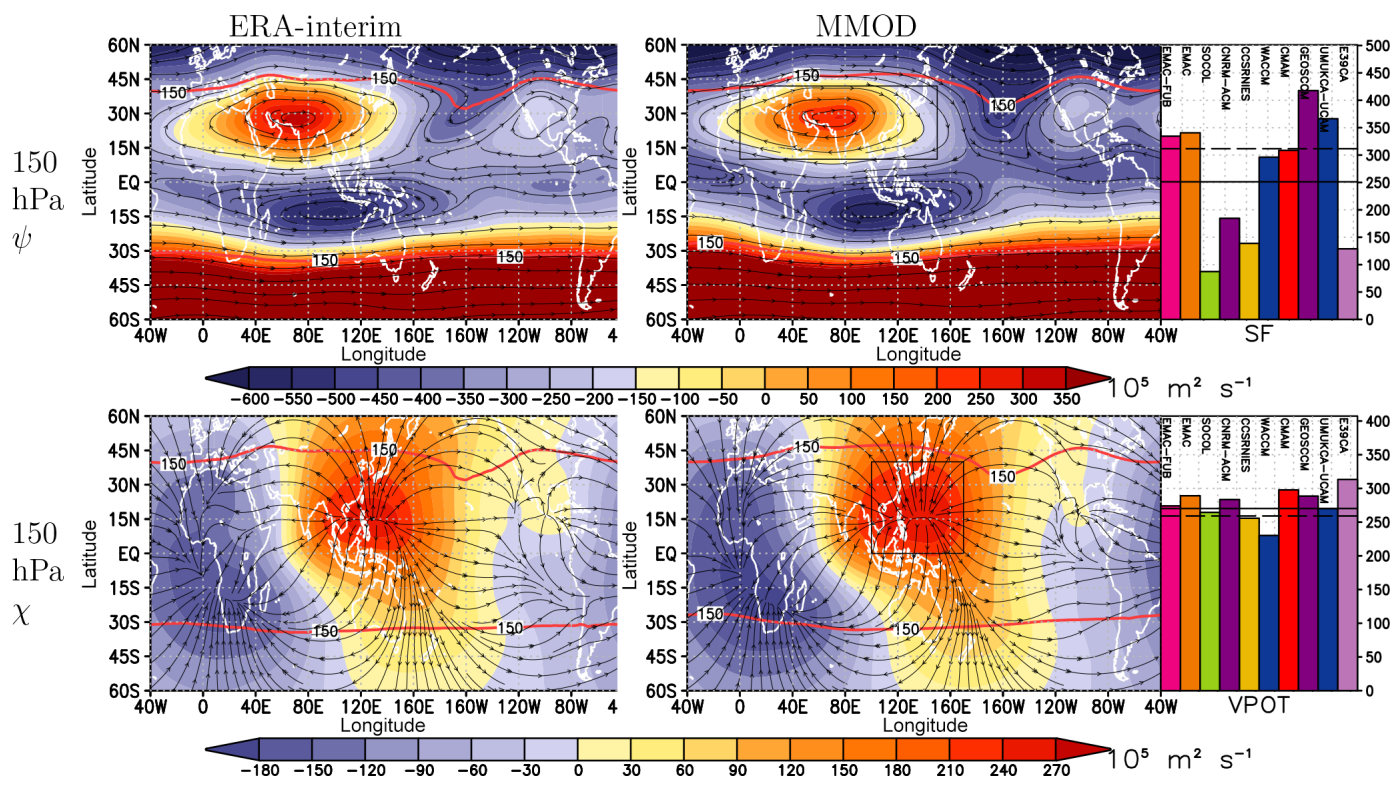

Figure 2. Top: long-term monthly-mean stream function (in $10^{5} \mathrm{~m}^{2} \mathrm{~s}^{-1}$ ) for JA at $150 \mathrm{hPa}$ in $60^{\circ} \mathrm{S}-60^{\circ} \mathrm{N}$; left: ERA-Interim (35 years); right: the multi-model average (45 years). Streamlines indicate the rotational horizontal wind. Indicated with the red solid contour is the intersect of the tropopause with $150 \mathrm{hPa}$. The maximum of individual models within the area marked by the black rectangle is displayed as a bar chart, where the solid horizontal line represents the multi-model average and the dashed horizontal line represents the maximum of ERA-Interim. Bottom: as above but for the velocity potential (in $10^{5} \mathrm{~m}^{2} \mathrm{~s}^{-1}$ ) with streamlines of the divergent horizontal wind.

North American monsoon regions that serve as a source region for $\mathrm{H}_{2} \mathrm{O}$.

To indicate the potential for further vertical uplift, the net radiative heating rate is shown on isentropic levels (indicated by the red contour lines in Figs. 3, 4, and 5, right). Positive values indicate ascent to levels of higher potential temperature. The mean radiative heating rates of the CCMs at the $360 \mathrm{~K}$ level are only positive at latitudes south of $\sim 20^{\circ} \mathrm{N}$ (including the $\mathrm{BoB}$ ). This indicates the possibility of slow uplift with upward transport of tracers in this region. For the region of the $\mathrm{H}_{2} \mathrm{O}$ maximum, centred around $30^{\circ} \mathrm{N}$ at 360 and $370 \mathrm{~K}$, however, the net radiative heating rates are negative, indicating descent. This highlights the important role of horizontal transport within the AMA, moving tracers away from the regions of convective outflow.

The temperatures on the lower level $(360 \mathrm{~K})$ show in both ERA-Interim and the multi-model average a maximum north-east of India (Fig. 4). With increasing height the local temperature minimum is developing within the AMA and extending northward. The lower temperatures within the AMA near the tropopause are described by Park et al. (2007) to be a result of the large-scale balanced dynamics induced by the ASM circulation.

$\mathrm{O}_{3}$ in the UTLS can better serve as a passive tracer than $\mathrm{H}_{2} \mathrm{O}$, due to its relatively long lifetime in the UTLS. A particular feature of the UTLS above the ASM is the low $\mathrm{O}_{3}$ mixing ratios confined within the AMA, which are caused by upwelling of lower-tropospheric air (Randel and Park, 2006; Park et al., 2007). As shown by Braesicke et al. (2011) with
GCM simulations using prescribed lower or higher $\mathrm{O}_{3}$ mixing ratios within the AMA, lower $\mathrm{O}_{3}$ mixing ratios have the tendency to strengthen and cool the AMA and vice versa. The MIPAS data show low $\mathrm{O}_{3}$ mixing ratios at all three isentropic levels (Fig. 5) with the most pronounced ozone minimum at $370 \mathrm{~K}$. Similar to the $\mathrm{H}_{2} \mathrm{O}$ maximum, the location of the MI$\mathrm{PAS}_{3}$ minimum is north-west of the region of the most intense convective activity. Unlike for $\mathrm{H}_{2} \mathrm{O}$, there is quite good agreement of the MMOD $\mathrm{O}_{3}$ mixing ratios with the MIPAS data. As indicated by MIPAS $\mathrm{O}_{3}$ data, tongues of air with high $\mathrm{O}_{3}$ mixing ratios are transported on the eastern flank of the AMA towards lower latitudes and form a ring of high $\mathrm{O}_{3}$ mixing ratios around the centre of the AMA at $380 \mathrm{~K}$. This feature was also discussed as in-mixing by Konopka et al. $(2009,2010)$ and Ploeger et al. (2012).

\subsection{Upper-tropospheric monsoon circulation}

As described in Sect. 3.2.1, the horizontal flow can be separated into a rotational part and a divergent part, the velocity potential. It can be further separated into a time mean component and a transient component, representing the Walker and monsoon circulations respectively (Tanaka et al., 2004).

Figure 6 shows the separation of the velocity potential into a component representing the Walker circulation (Fig. 6, top) and a component representing the monsoon circulation (Fig. 6, bottom). The position of the maximum upwelling for individual years is marked with open circles, where the size of the circle represents the strength of the upwelling. For the 


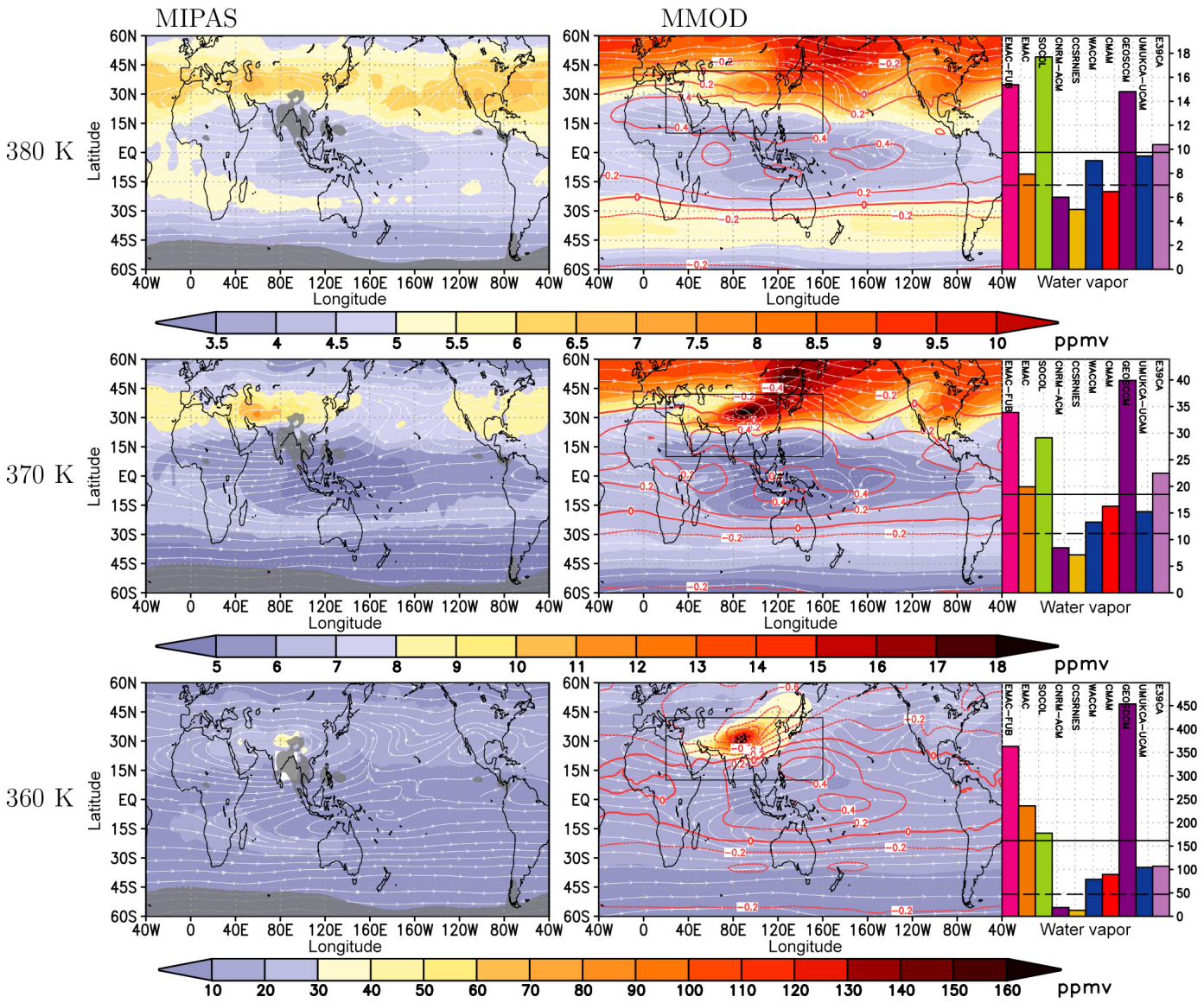

Figure 3. Long-term monthly-mean $\mathrm{H}_{2} \mathrm{O}$ mixing ratios in ppmv for $\mathrm{JA}$ at 360 , 370, and $380 \mathrm{~K}$ (from bottom to top) for latitudes from $60^{\circ} \mathrm{S}$ to $60^{\circ} \mathrm{N}$; left: MIPAS $(2003,2005-2011)$, overlaid grey shaded regions where the OLR $\leq 205 \mathrm{~W} \mathrm{~m}^{-2}$; right: the multi-model average (45 years). Overlaid as streamlines are the horizontal wind components; red contours indicate the net radiative heating rates in $\mathrm{Kday}^{-1}$. The maximum of individual models within the area marked by the black rectangle is displayed as bar chart, where the solid horizontal line represents the MMOD and the dashed horizontal line represents the maximum of MIPAS.

annual average the region of strongest upwelling, related to the Walker circulation (Fig. 6, top), is located over the equatorial western Pacific, in most years to the north-west of New Guinea. The main region of downwelling extends from the central Sahara to western Africa, whereas a secondary centre of downwelling is located off the coast of Peru.

The centre of the strongest upwelling related to the monsoon circulation (Fig. 6, bottom) is located over Southeast Asia, with the centres of individual years located in a region extending from the BoB to eastern China. This area partly overlaps with the region of the lowest OLR (see Fig. 3) and therefore the monsoon circulation index, derived from the maxima in the seasonal decomposition of the velocity potential, is a good indicator for the overall strength of the monsoon circulation. Although the ERA-Interim climatological average of both decompositions (annual average associated with the Walker circulation and seasonal average associated with the monsoon circulation) is slightly lower than for the
MMOD, the shape and the locations of the maxima for individual years in the CCMs are quite similar.

\section{Interannual variability of temperature, $\mathrm{H}_{2} \mathrm{O}$, and $\mathrm{O}_{3}$ in the UTLS}

So far we have characterized the climatological behaviour. Here, we characterize the dominant internal modes of interannual variability like ENSO, the QBO, or the monsoonal variability. Although there is evidence of a coupling between the ASM and ENSO through the Walker circulation (e.g. Webster and Yang, 1992; Ju and Slingo, 1995), we make an attempt to separate the influence of the ASM and ENSO on the UTLS temperatures, the $\mathrm{H}_{2} \mathrm{O}$, and $\mathrm{O}_{3}$ mixing ratios by applying a MLR model as described in Sect. 3.2.2. We analyse the influence of the monsoon circulation, ENSO, and QBO on the transport characteristic of the AMA.

The regression coefficients of the individual CCMs are combined by a simple average for the CCMs listed in Ta- 


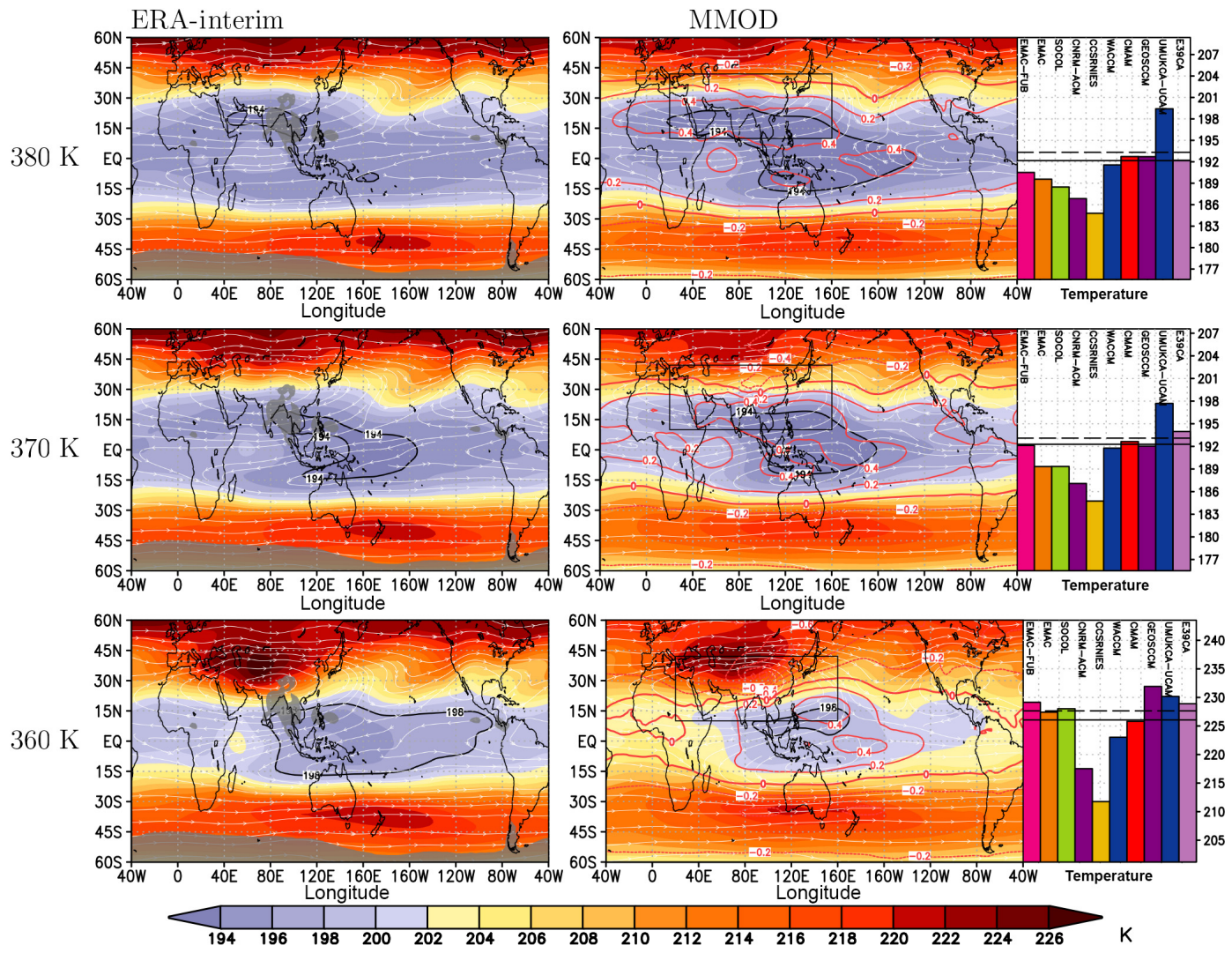

Figure 4. As Fig. 3 but for temperature. Left column: JA ERA-Interim temperature averaged from 1979 to 2014 . Contour lines for the lowest temperatures of the multi-model average are given in black: $296 \mathrm{~K}$ (at $360 \mathrm{~K}$ ) and $294 \mathrm{~K}$ (at 370 and $380 \mathrm{~K}$ ). At 370 and $380 \mathrm{~K}$ the minimum (at $360 \mathrm{~K}$ the maximum) of individual models within the area marked by the black rectangle is displayed as bar chart, where the solid horizontal line represents the MMOD and the dashed horizontal line represents the value for ERA-Interim.

ble 1. The results of the $t$ tests of the MLR results for the individual CCMs are combined by using the $Z$ transform method (Stouffer et al., 1949; Whitlock, 2005). Regions where the combined regression coefficients are not significant are marked by grey shading, overlaid on the colour shading used to emphasize the regions with the largest regression coefficients.

\subsection{Influence of the monsoon circulation}

The influence of the strength of the Asian summer monsoon on $\mathrm{H}_{2} \mathrm{O}$ and $\mathrm{O}_{3}$ mixing ratios in CCMs and ERA-40 data has been analysed in Kunze et al. (2010) by separating the data according to the monsoon Hadley index (MHI) in weak and strong ASM seasons. During stronger ASM seasons, $\mathrm{H}_{2} \mathrm{O}$ and $\mathrm{O}_{3}$ were found to be anticorrelated, with lower $\mathrm{O}_{3}$ and higher $\mathrm{H}_{2} \mathrm{O}$ mixing ratios within the AMA, as a result of stronger convective activity during stronger ASM seasons. In contrast to the MHI, the now-used MIDX is a more direct measure for the ASM strength. Randel et al. (2015) used a different approach in distinguishing between wet and dry phases in the AMA to identify the conditions leading to either dry or wet $\mathrm{H}_{2} \mathrm{O}$ extrema. During the wet phase they found reduced convection over the regions of strongest convective activity. The corresponding temperature anomalies, linked to reduced convection, show a dipole structure with warmer conditions on the southern edge of the AMA during wet phases with the oppositely signed structure evident in the dry phases. They therefore conclude that during weaker ASM seasons less effective dehydration in the warm anomaly at the southern edge of the AMA is responsible for the higher $\mathrm{H}_{2} \mathrm{O}$ mixing ratios within the AMA.

In order to further elucidate the role of the monsoon intensity on UTLS temperature, $\mathrm{H}_{2} \mathrm{O}$, and $\mathrm{O}_{3}$ content, we perform an MLR analysis using the MIDX. As MIDX is a direct measure of the upper-tropospheric divergence largely induced by the ASM, the regression patterns represent the changes due to an increase in ASM activity. Positive regression coefficients in strong monsoon years (MIDX $\gg 0$ ) indicate regions that tend to be warmer or have increased $\mathrm{H}_{2} \mathrm{O}$ or $\mathrm{O}_{3}$ mixing ratios. Negative regression coefficients indicate regions where strong monsoons lead to cooling or decreased $\mathrm{H}_{2} \mathrm{O}$ or $\mathrm{O}_{3}$ mixing ratios.

The MIDX regression coefficients for the JA average NOAA OLR (Fig. 7a) show a similar pattern as shown by 


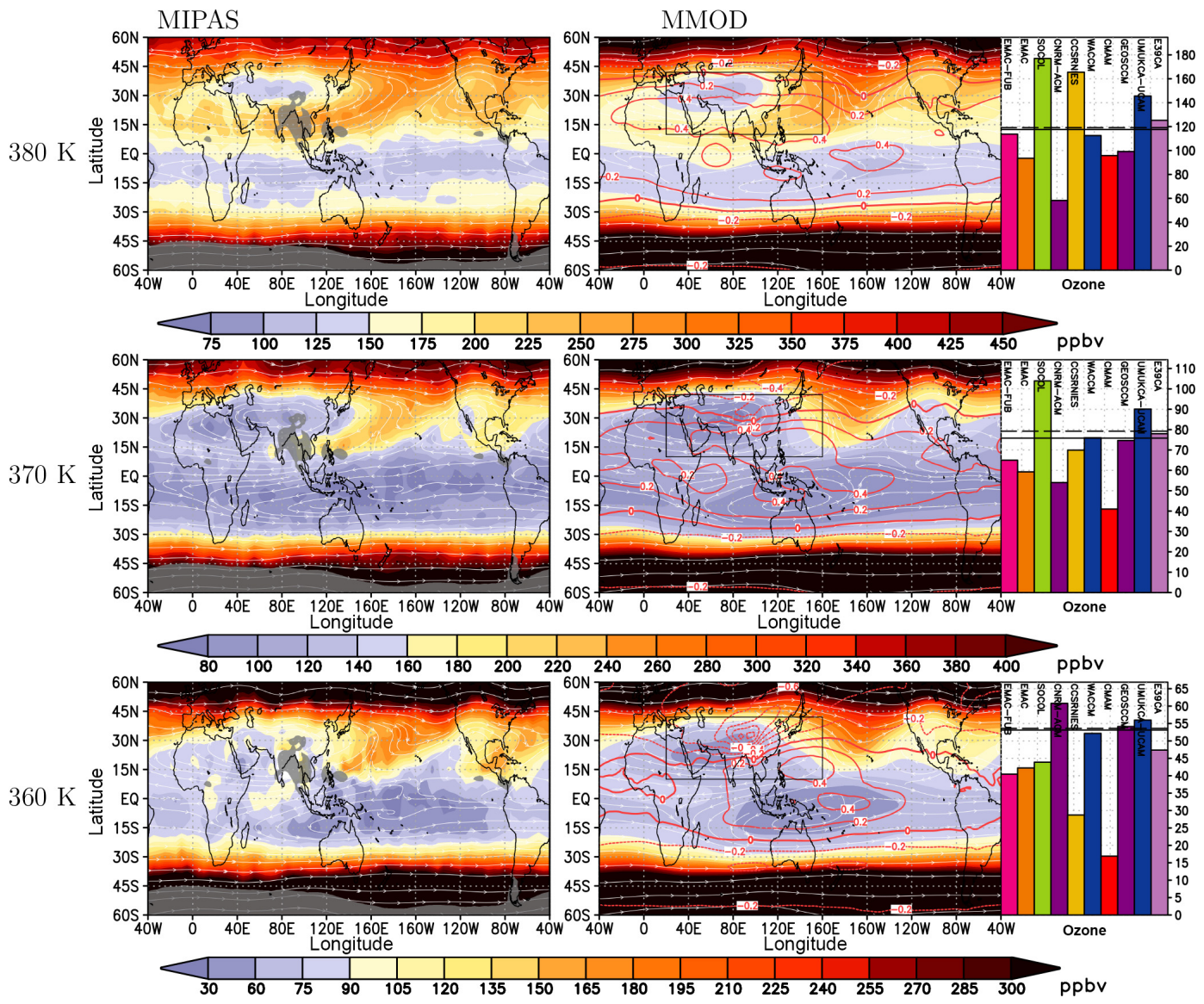

Figure 5. As Fig. 3 but for ozone in ppbv. The minimum of individual models within the area marked by the black rectangle is displayed as bar charts, where the solid horizontal line represents the MMOD and the dashed horizontal line represents the minimum of MIPAS.

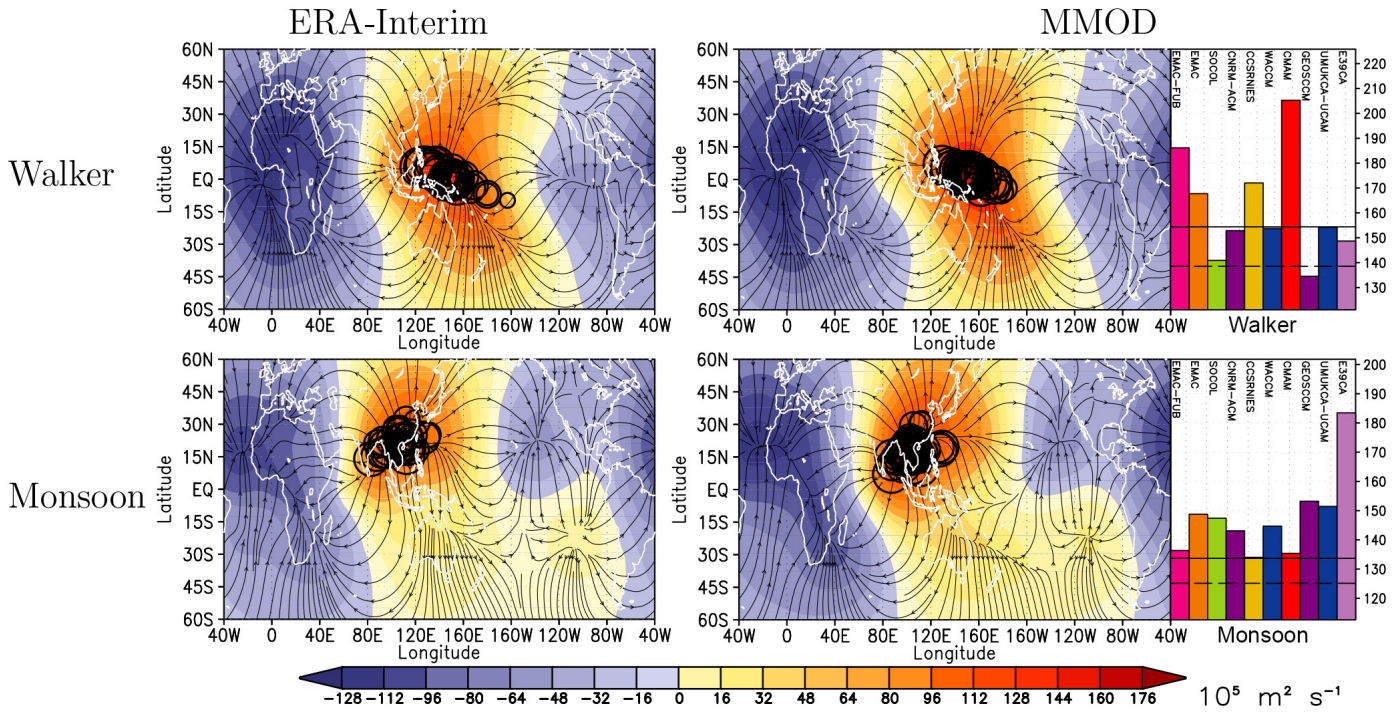

Figure 6. Top: Annual mean climatology of the $\operatorname{MMOD} \bar{\chi}^{*}(x, y)$ (velocity potential at $150 \mathrm{hPa}$ after subtracting the zonal average), representing the divergent flow associated with the Walker circulation; (left) for ERA-Interim (1979-2014); (right) for the multi-model average of the CCMs. Bottom: JA climatology of $\chi^{* \prime}(t, x, y)$ (the velocity potential at $150 \mathrm{hPa}$ after subtracting the zonal average and annual average), representing the divergent flow associated with the ASM. Black circles mark the position of the maximum velocity potential for individual years. The bar charts on the right indicate the maximum climatological velocity potential for the individual CCMs; the solid horizontal line represents the MMOD and the dashed horizontal line represents the maximum of ERA-Interim. 
Randel et al. (2015) (R15) (their Fig. 5a) for the wet case with a significant decrease in OLR, indicating colder cloud tops, i.e. stronger convective activity, over the Indian subcontinent and the Arabian sea and a decrease in convective activity over the central BoB, the TP, and East China Sea. For stronger monsoon seasons we also get an increase in convective activity over the southern part of the $\mathrm{BoB}$, the western coast of Myanmar, and Hanai, which is in contrast to the results of R15. This decrease of OLR with monsoon activity is partly coincident with the regions of strongest convection, indicated by the OLR $<205 \mathrm{~W} \mathrm{~m}^{-2}$ (white contour line in Fig. 7a). The MIDX regressed on ERA-Interim $100 \mathrm{hPa}$ temperatures reproduces the anomalous dipole temperature structure with lower temperatures at the northern and higher temperatures at the southern edge of the AMA, but the patterns are more similar to the inverse of that shown by R15 (their Fig. 8b) for the dry case, with a significant warming to the south-east of the AMA and two cold anomalies located on the western side and on the north-eastern flank of the AMA (Fig. 7b). From our analyses for the MIDX regression on ERA-Interim temperatures and $\mathrm{H}_{2} \mathrm{O}$ mixing ratios (Fig. 7c) we conclude that during a stronger monsoon season $\mathrm{H}_{2} \mathrm{O}$ mixing ratios should increase within the AMA. The reason for the discrepancy with R15 may be related to the different analysis period (2005-2013) used in their study. When we apply their method but based on daily $100 \mathrm{hPa}$ ERA-Interim $\mathrm{H}_{2} \mathrm{O}$ extrema from May to September for the years 2005-2013, we can reproduce the main features of their OLR and temperature anomaly patterns. When we repeat the analyses with data covering only July to August but using the years from 1979 to 2013, we can confirm the decrease in convective activity over the southern TP for the wet composite; however, for the adjacent region in the south (extending from the Indian subcontinent, the BoB, to Vietnam) we get the opposite anomalies with more intense convective activity for the wet composite and reduced convective activity for the dry composite (see Figs. S5 and S6 in the Supplement).

The analyses on the $380 \mathrm{~K}$ isentropic surface (Fig. 8a) show similar anomaly patterns within the Asian monsoon region as analysed for $100 \mathrm{hPa}$. The MIDX regressed on the ERA-Interim $\mathrm{H}_{2} \mathrm{O}$ and $\mathrm{O}_{3}$ mixing ratios shows a significant increase in $\mathrm{H}_{2} \mathrm{O}$ and a decrease in $\mathrm{O}_{3}$ within the AMA. The largest negative $\mathrm{O}_{3}$ anomalies coincide well with the two regions of cooling and the anomalous anticyclonic horizontal flow as indicated by the streamlines of the horizontal wind components, regressed on the MIDX. This indicates upwelling of lower-tropospheric, $\mathrm{O}_{3}$-poor, and humid air that accumulates inside the AMA. Park et al. (2007) describe the lower temperature within the AMA near the tropopause as a result of the large-scale balanced dynamics and not as the result of convective overshooting. They also describe the decoupling of the $\mathrm{H}_{2} \mathrm{O}$ maximum within the AMA near the tropopause from the region of strongest convection. The anomaly pattern seems to suggest similar processes for seasons with higher MIDX. The MIDX regression coefficients
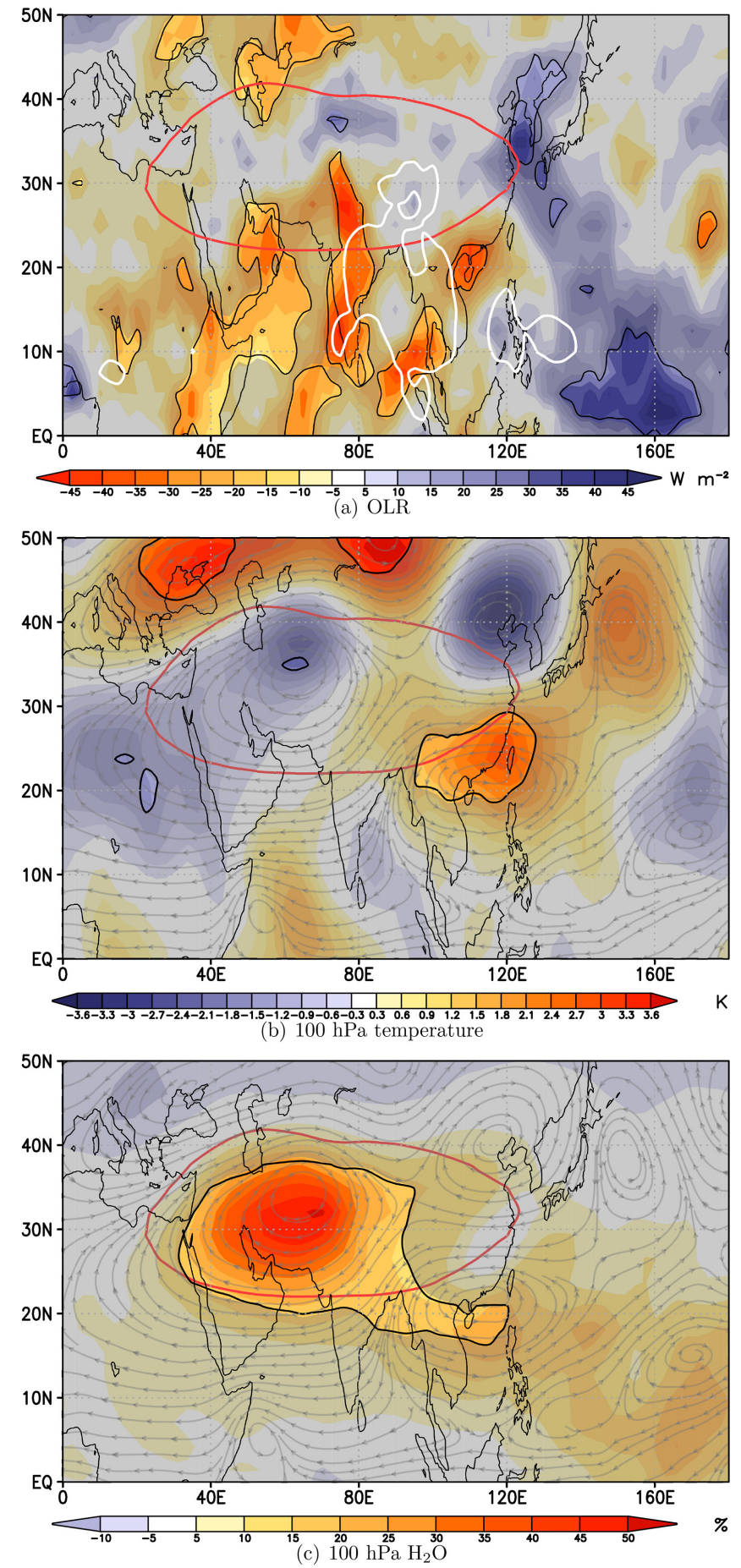

Figure 7. Regression coefficients from MLR for the MIDX of JA average data, with (a) NOAA OLR, (b) ERA-Interim $100 \mathrm{hPa}$ temperature, and (c) ERA-Interim $100 \mathrm{hPa} \mathrm{H}_{2} \mathrm{O}$. The $205 \mathrm{~W} \mathrm{~m}^{-2}$ contour line of NOAA OLR is plotted in white on panel (a). Red contours of the $16750 \mathrm{~m}$ geopotential height at $100 \mathrm{hPa}$ mark the position of the AMA. Grey streamlines on panels (b) and (c) mark the horizontal wind components, regressed on the MIDX. Overlaid grey shading indicates regions where the regression is not significant at the $95 \%$ level. 

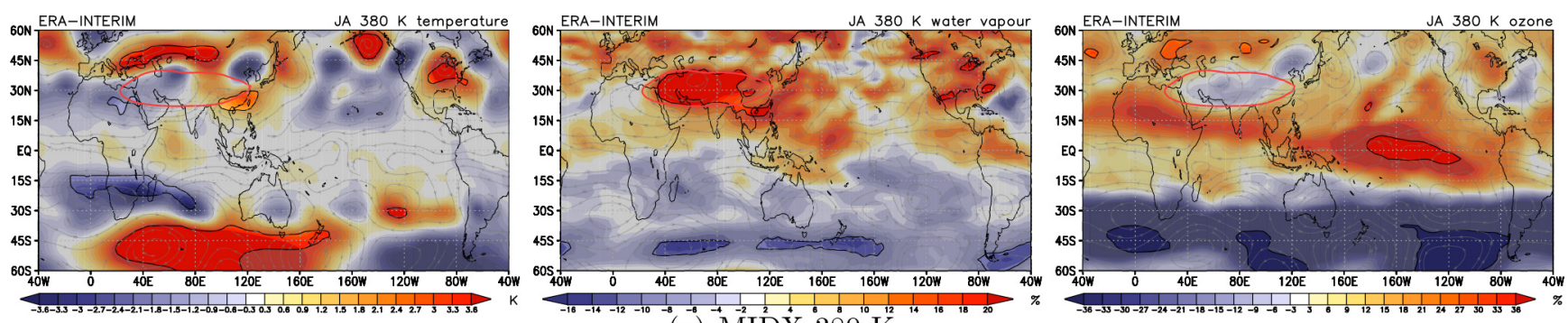

(a) MIDX $380^{-2} \mathrm{~K}$
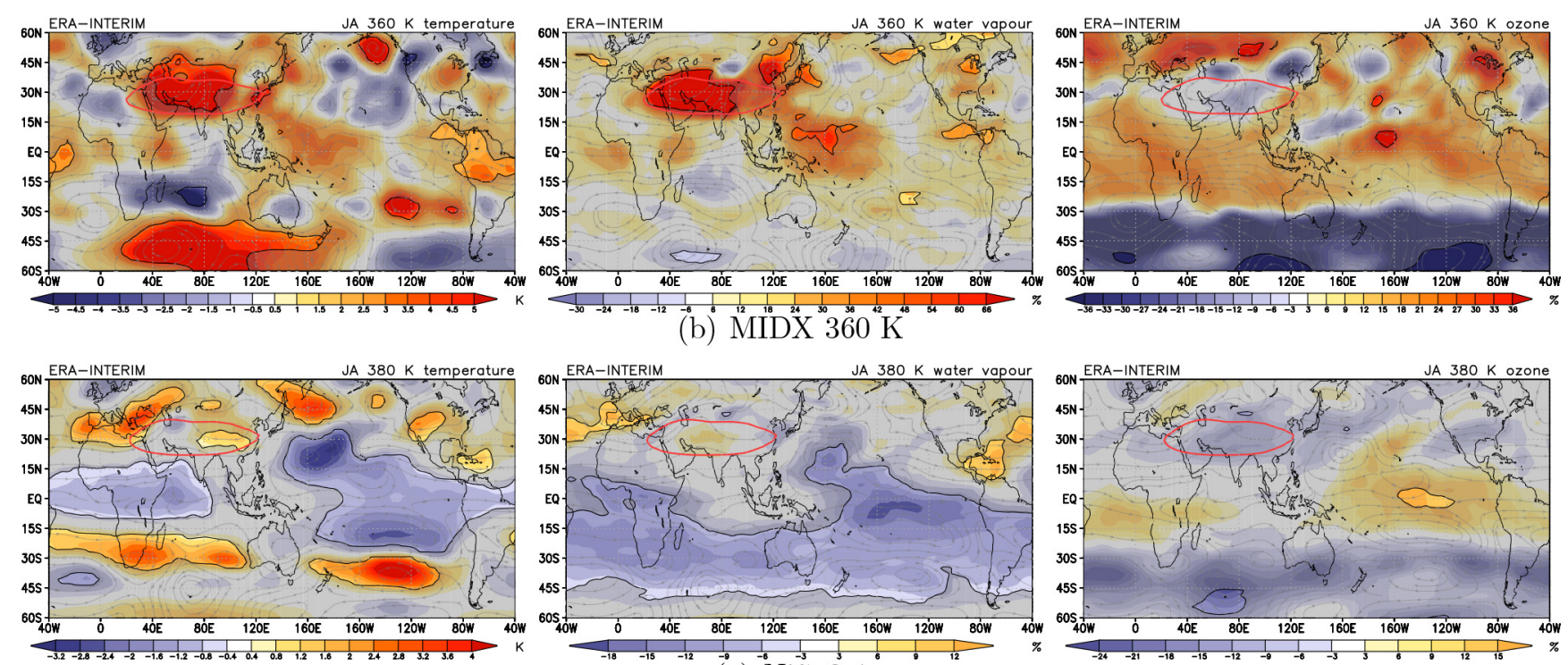

(c) Niño3.4
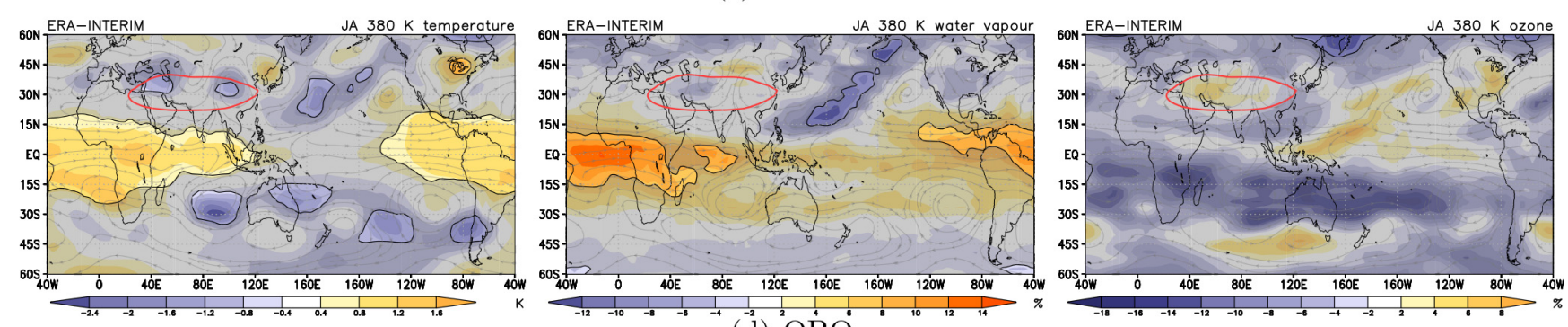

(d) ${ }^{2} \mathrm{QBO}$

Figure 8. Regression coefficients from MLR of ERA-Interim data, for the monsoon circulation index (a) on $380 \mathrm{~K}$ and (b) on $360 \mathrm{~K}$, (c) the Niño3.4 index, and (d) the QBO time series on the $380 \mathrm{~K}$ isentropic level; temperature (left), water vapour (middle), and ozone (right). The regression coefficients for the $\mathrm{H}_{2} \mathrm{O}$ and $\mathrm{O}_{3}$ mixing ratios are displayed in percent of the long-term average of the respective JA average. The red contour of the Montgomery stream function marks the position of the AMA: $3625 \times 10^{2} \mathrm{~m}^{2} \mathrm{~s}^{-2}$ on $380 \mathrm{~K}, 3513 \times 10^{2} \mathrm{~m}^{2} \mathrm{~s}^{-2}$ on $360 \mathrm{~K}$ Overlaid grey shading marks regions where the regression is not significant at the $95 \%$ level.

on the $360 \mathrm{~K}$ level (Fig. 8b) show for $\mathrm{H}_{2} \mathrm{O}$ and $\mathrm{O}_{3}$ similar patterns as on $380 \mathrm{~K}$, whereas the MIDX regression on temperatures shows a large warming of the AMA. This warming with increasing ASM activity is also present at the southeastern edge of the AMA on the $380 \mathrm{~K}$ level and seems to maintain the $\mathrm{H}_{2} \mathrm{O}$ increase.

The regression coefficients of the MIDX on MMOD CCM temperatures, $\mathrm{H}_{2} \mathrm{O}$, and $\mathrm{O}_{3}$ on the 360,370 , and $380 \mathrm{~K}$ isentropic surfaces (Fig. 9) indicate large areas with significant influences of the ASM, not only confined to the ASM re- gion. On the $360 \mathrm{~K}$ level in the upper troposphere, a temperature increase with increasing ASM activity by about $5 \mathrm{~K}$ is located within the AMA over the TP, coinciding with an increase in $\mathrm{H}_{2} \mathrm{O}$ by $65 \%$. The TP acts as an elevated heat source in the mid-troposphere, which makes a major contribution in forming the AMA, as shown by Liu et al. (2007). Convective events released over the TP more often reach the tropopause than over the BoB (Fu et al., 2006). South of the AMA, the regression results on the 370 and $380 \mathrm{~K}$ isentropes indicate a cooling over the eastern Indian ocean and west- 

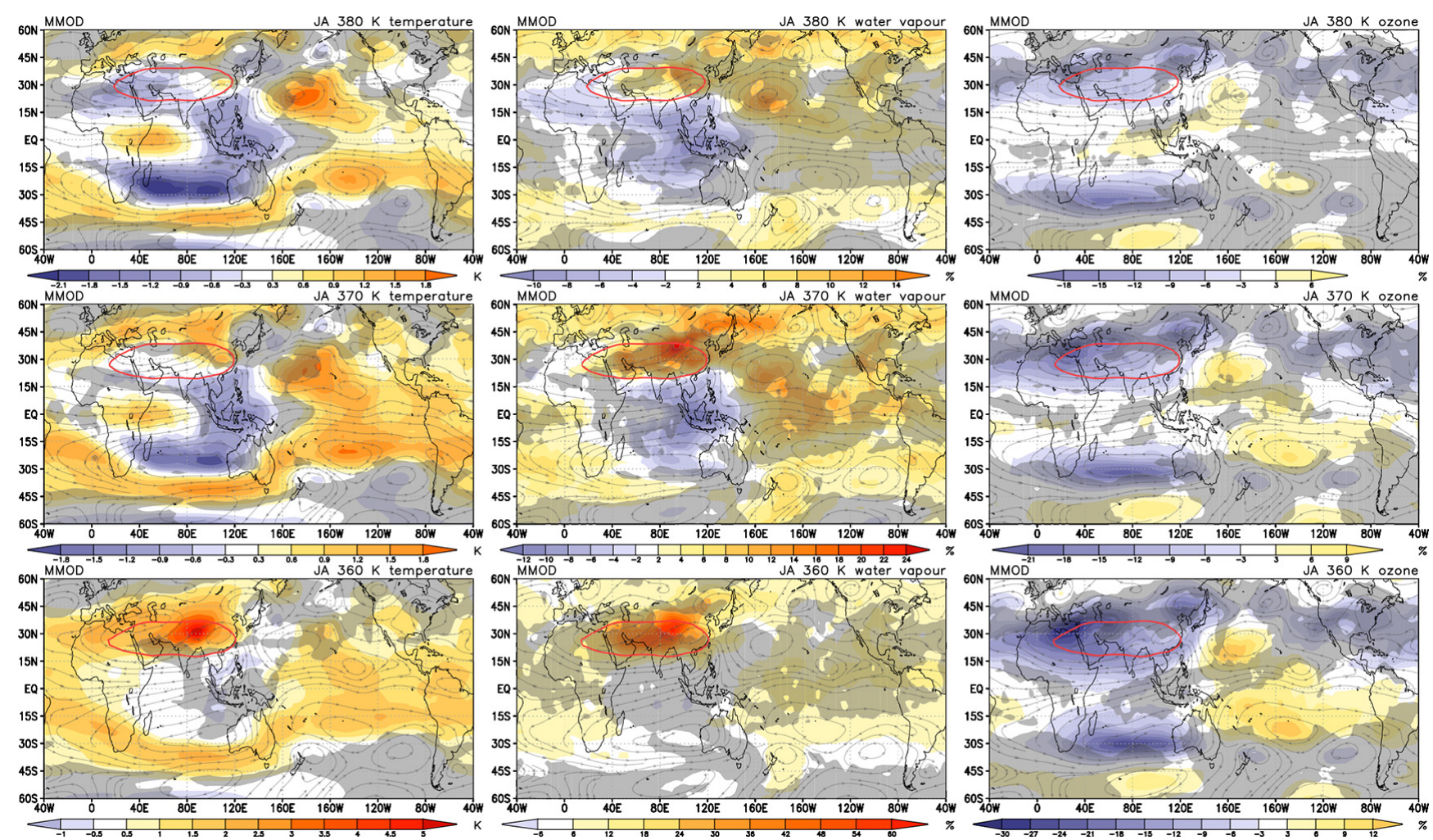

Figure 9. Multi-model average of the CCMs of the regression coefficient of the monsoon circulation index (MIDX) with temperature (left), $\mathrm{H}_{2} \mathrm{O}$ (middle), and $\mathrm{O}_{3}$ (right) on isentropic levels 360 , 370, and $380 \mathrm{~K}$ (from bottom to top). The regression coefficients of the $\mathrm{H}_{2} \mathrm{O}$ and $\mathrm{O}_{3}$ mixing ratios are displayed in percent of the long-term average of the respective JA average. Grey streamlines show the horizontal wind components, regressed on the MIDX. The red contours of the Montgomery stream function $(360 \mathrm{~K}: 3513,370 \mathrm{~K}: 3570$, $380 \mathrm{~K}: 3625$, in $10^{2} \mathrm{~m}^{2} \mathrm{~s}^{-2}$ ) mark the position of the AMA. Overlaid grey shading marks regions where the regression is not significant at the $97.5 \%$ level.

ern Pacific warm pool, coinciding with decreasing $\mathrm{H}_{2} \mathrm{O}$ concentrations. These patterns of temperature anomalies, corresponding to strong ASM seasons, contrast the temperature pattern on $380 \mathrm{~K}$ for ERA-Interim (Fig. 8a, left), showing a positive temperature anomaly at the south-eastern edge of the AMA. However, the positive $\mathrm{H}_{2} \mathrm{O}$ anomalies within the AMA prevail on the 370 and $380 \mathrm{~K}$ isentropes.

The largest MMOD $\mathrm{O}_{3}$ decrease of $36 \%$ on the $360 \mathrm{~K}$ isentropic level is located over the Eastern Mediterranean Sea, the western flank of the AMA, and a secondary $\mathrm{O}_{3}$ decrease by $24 \%$ is located over north-eastern China at the eastern flank of the AMA. The pattern of the $\mathrm{O}_{3}$ regression coefficients is slightly decreasing but persistent in height. The strongest MMOD temperature and $\mathrm{H}_{2} \mathrm{O}$ signals of the MIDX seem to be decoupled from that in $\mathrm{O}_{3}$, which might be an indication of the more complex nature of $\mathrm{H}_{2} \mathrm{O}$, as it can change its phase during transport in regions of dehydration. With increasing height, on 370 and $380 \mathrm{~K}$, the influence of the monsoon circulation on temperature within the AMA is decaying, whereas a temperature dipole becomes obvious with decreasing temperatures over Indonesia and the western Pacific warm pool and increasing temperatures over the subtropical regions of the central Pacific during strong monsoon seasons. Increasing $\mathrm{H}_{2} \mathrm{O}$ concentrations are still present in the AMA at 370 and $380 \mathrm{~K}$, although weaker than at $360 \mathrm{~K}$, with 24 and $14 \%$ respectively.

\subsection{Influence of ENSO}

The ENSO influence on the zonal mean temperatures from nine reanalyses data sets has been analysed by Mitchell et al. (2014), showing a warming in the tropical troposphere during ENSO warm events. Towards the tropical tropopause region this warming turns into a cooling. However, the main ENSO signature on temperatures in the tropics has strong longitudinal variation, mainly over the Pacific, which partly cancel each other when analysing zonal averages (Randel et al., 2000).

The Niño3.4 regression coefficients on ERA-Interim temperatures and $\mathrm{H}_{2} \mathrm{O}$ mixing ratios (Fig. 8c) emphasize the zonal asymmetric response with the typical horse shoe pattern of decreasing temperatures with increasing SSTs in the Niño3.4 region during an ENSO warm event. Simultaneously, anticyclonic circulation cells to the north-west and south-west and low $\mathrm{H}_{2} \mathrm{O}$ mixing ratios develop. This kind of pattern was first identified by Gill (1980) in an idealized 

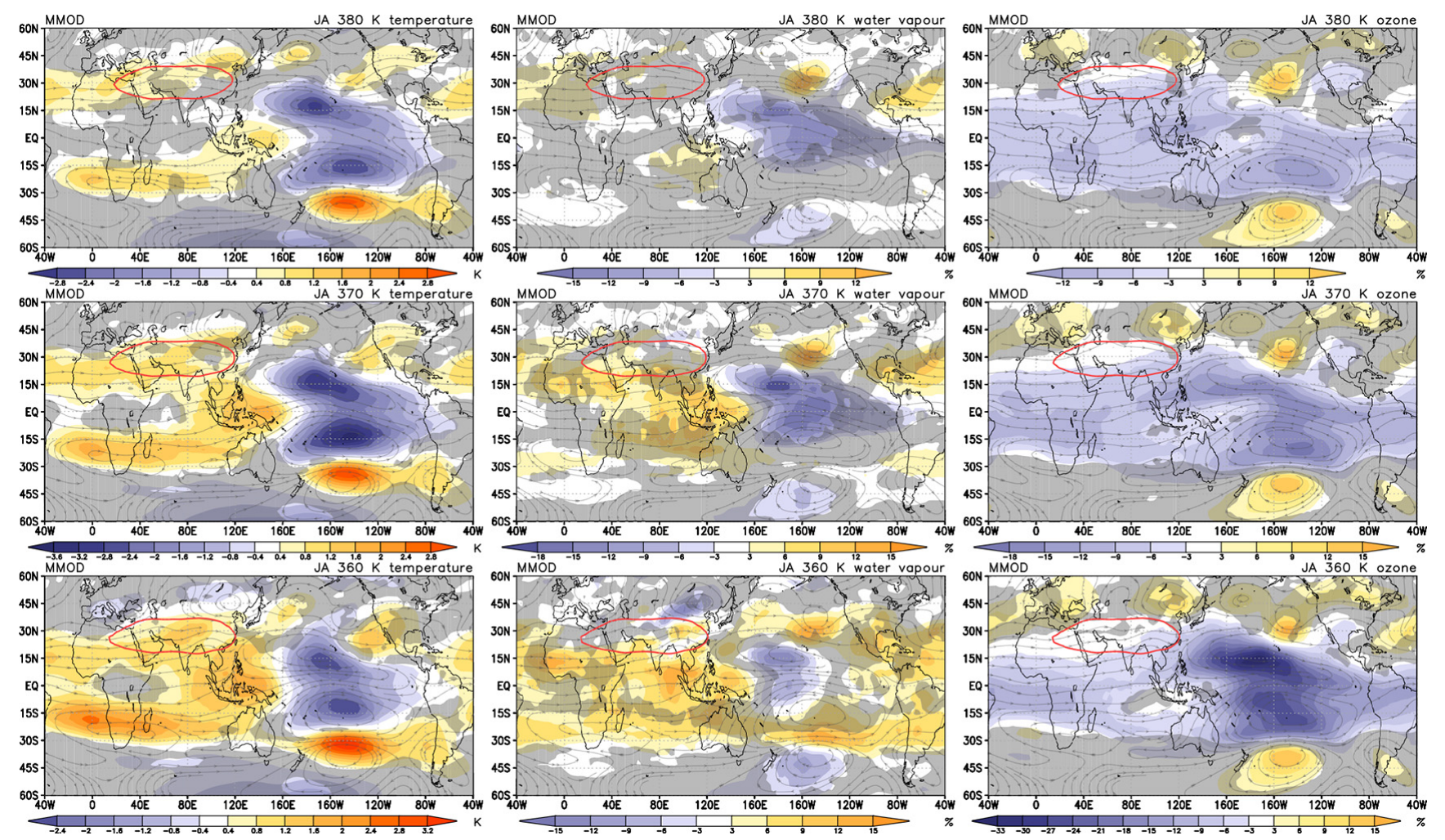

Figure 10. As Fig. 9 but for the Niño3.4 index.

model as the dynamic response to a heat source centred at the Equator. A similar pattern was also found in reanalysis fields in the TTL by Gettelman et al. (2001) and Zhou et al. (2001) to be caused by El Niño events. The Niño3.4 regression on ERA-Interim $\mathrm{O}_{3}$ mixing ratios shows an unexpected positive response in the central Pacific, whereas a negative signal would be more plausible due to the outflow of $\mathrm{O}_{3}$-poor air above the eastward-shifted convection during El Niño events. This feature reveals the limitations of the ERA-Interim $\mathrm{O}_{3}$ data.

We find the strongest impact on the CCM temperatures at the $370 \mathrm{~K}$ level with two centres located at $15^{\circ} \mathrm{S}$ and $15^{\circ} \mathrm{N}$ near $160^{\circ} \mathrm{W}$, slightly decaying at $380 \mathrm{~K}$ and less pronounced at $360 \mathrm{~K}$ (Fig. 10). The shift of convection towards the central pacific with less intense convection over Indonesia creates a dipole consisting of a cold and dry anomaly in the UTLS above the central Pacific and a warm and wet anomaly above the western Pacific warm pool. These structures are quite the opposite to the regression patterns from the MIDX time series, indicating the higher probability of strong ASM seasons during La Niña events. The influence of ENSO warm events on the UTLS temperatures and $\mathrm{H}_{2} \mathrm{O}$ mixing ratios in the ASM region is less pronounced than the influence derived for the MIDX, and, even though warming prevails for ENSO warm events above the ASM region, there is no significant increase in $\mathrm{H}_{2} \mathrm{O}$ mixing ratios north of $30^{\circ} \mathrm{N}$. The higher $\mathrm{H}_{2} \mathrm{O}$ concentrations during ENSO warm events span from the western Pacific towards Africa in the longitudinal direction and extend only to near south of $30^{\circ} \mathrm{N}$ in the ASM region. To the north over the TP the Niño3.4 regression coefficients on $\mathrm{H}_{2} \mathrm{O}$ indicate an insignificant decrease in mixing ratios. The highest percentage changes in $\mathrm{O}_{3}$ concentrations during ENSO warm events are found at $360 \mathrm{~K}$, again with a typical horse-shoe-like pattern, showing a stronger impact in the northern subtropics. The influence of ENSO on $\mathrm{O}_{3}$ seems to be weaker on the 370 and $380 \mathrm{~K}$ level.

The comparison of the Niño3.4 with the MIDX regression coefficients (Fig. 9) reveals the similarity of the strong ASM cases with La Niña conditions which we suppose to be opposite the El Niño conditions as shown in Fig. 10. This is supported by the results of the Niño3.4 regression with ERA-Interim data, showing also a double peak structure of decreasing temperatures in the subtropics of the central Pacific and increasing temperatures above the western Pacific warm pool during El Niño events. This temperature pattern is also reflected to a certain degree in the $\mathrm{H}_{2} \mathrm{O}$ mixing ratios, whereas the regression results for $\mathrm{O}_{3}$ are not significant.

\subsection{Influence of the quasi-biennial oscillation}

The QBO is characterized by downward-propagating vertical shear zones of the zonal wind. Westerly (easterly) shear zones create positive (negative) temperature anomalies, according to the thermal wind balance. To maintain the 

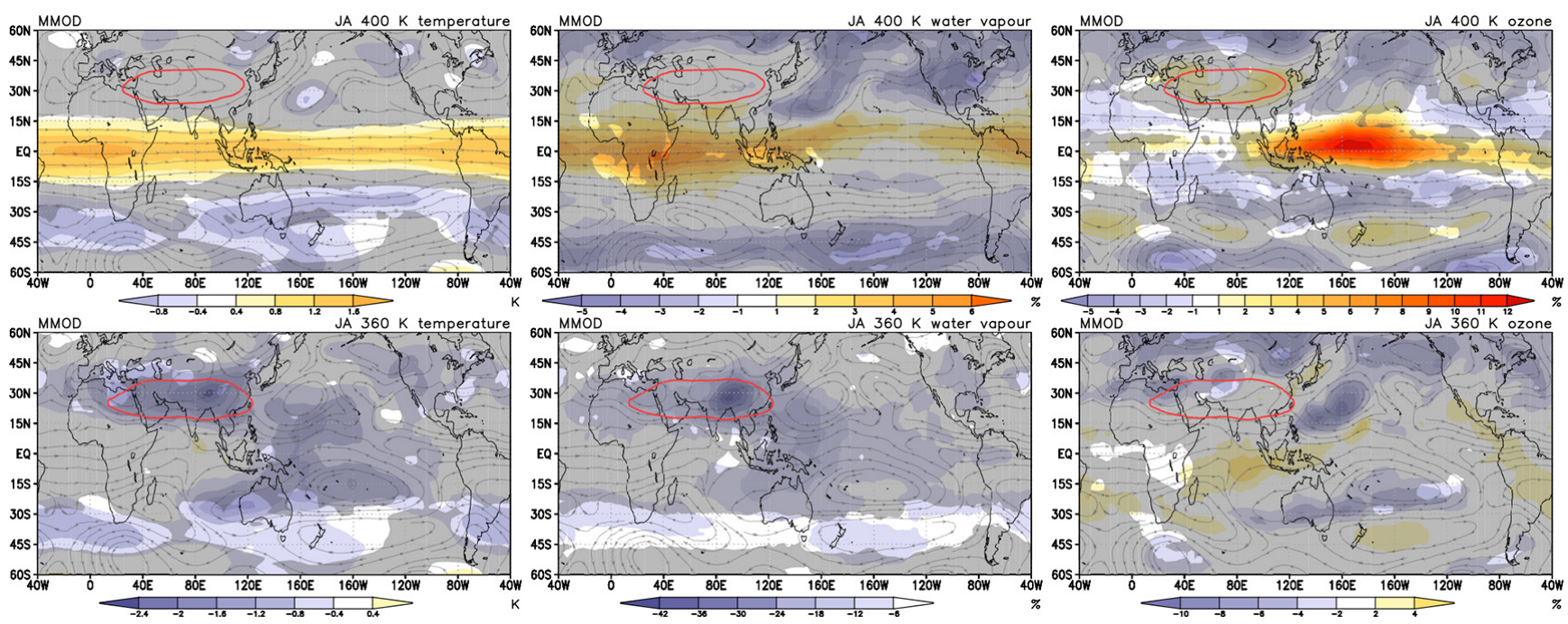

Figure 11. As Fig. 9 but for the quasi-biennial oscillation on the isentropic levels 360 and $400 \mathrm{~K}$ (from bottom to top), including the CCMs: CCSRNIES, EMAC, EMAC-FUB, E39CA, SOCOL, UMUKCA-UCAM, and WACCM. The contour level for the $400 \mathrm{~K}$ Montgomery stream function is $3730 \times 10^{2} \mathrm{~m}^{2} \mathrm{~s}^{-2}$.

QBO in temperatures, a secondary mean meridional circulation (MMC) arises with equatorial relative downwelling (upwelling) in westerly (easterly) shear zones of the zonal wind (Plumb and Bell, 1982). The QBO therefore modulates the strength of the prevailing upwelling in the equatorial lower and middle stratosphere. To ensure continuity, the air is forced to move upward (downward) in the subtropics when relative downwelling (upwelling) occurs at the Equator. Above and below the region of maximum relative downwelling, convergent and divergent motion closes this QBOinduced MMC. The QBO thereby affects the temperatures at the tropical tropopause (Zhou et al., 2001) and has the ability to modify the $\mathrm{H}_{2} \mathrm{O}$ concentrations entering the lower stratosphere (Giorgetta and Bengtsson, 1999). The QBO-induced MMC is known to also affect $\mathrm{O}_{3}$ transport with downwelling of $\mathrm{O}_{3}$-rich air in a westerly shear zone, thereby generating a QBO in $\mathrm{O}_{3}$ mixing ratios (e.g. Cordero et al., 1997; Logan et al., 2003).

The QBO regression coefficients can be interpreted to represent the changes of the temperatures and the $\mathrm{H}_{2} \mathrm{O}$ and $\mathrm{O}_{3}$ mixing ratios forced by a mean amplitude between the easterly to westerly phase of the QBO. The modulation of the ERA-Interim $380 \mathrm{~K}$ temperatures by the QBO (Fig. 8d) shows a significant increase in the inner tropics extending from the eastern Pacific to the Indian Ocean and some regions of decreasing temperatures in the subtropics, consistent with the QBO-induced circulation changes. The changes in $\mathrm{H}_{2} \mathrm{O}$ mixing ratios are consistent with the temperature changes, with increasing $\mathrm{H}_{2} \mathrm{O}$ mixing ratios in the inner tropics where temperature increase is induced and decreasing $\mathrm{H}_{2} \mathrm{O}$ mixing ratios in the extratropics. There is a remarkable gap in the QBO regression pattern for the temperatures and $\mathrm{H}_{2} \mathrm{O}$ mixing ratios over the equatorial western Pacific, as probably some of the QBO-induced variability might be described by the Niño3.4 index. The insignificant $\mathrm{O}_{3}$ regression patterns shown for $380 \mathrm{~K}$ are very similar on the isentropic levels 360 and $370 \mathrm{~K}$ (not shown) and do not show a plausible response to the QBO, which might be caused by assimilating total column ozone.

To emphasize the height dependence of the QBO influence, the QBO regression results of the CCM data that include a QBO in Fig. 11 are shown for the 360 and $400 \mathrm{~K}$ isentropic surfaces. The temperatures increase close to the Equator at $400 \mathrm{~K}$, as the adiabatic cooling is suppressed in the regions of less upwelling. The strongest increase of more than $1.5 \mathrm{~K}$ occurs near equatorial Africa. The temperature decreases in the subtropics in both hemispheres as a result of the QBO-induced MMC that creates anomalous rising of air.

The QBO regressions on the $400 \mathrm{~K} \mathrm{H}_{2} \mathrm{O}$ mixing ratios show the expected increase near the Equator, due to the anomalously high equatorial temperatures, and also an increase in $400 \mathrm{~K} \mathrm{O}_{3}$, due to anomalous downwelling of $\mathrm{O}_{3^{-}}$ rich air. The QBO signal is more clear and consistent among the CCMs for temperature than for the $\mathrm{O}_{3}$ and the $\mathrm{H}_{2} \mathrm{O}$ mixing ratios. Similar to the ERA-Interim data, there is a deviation from the zonal nature of the QBO signal, as pronounced in temperatures, over the equatorial central Pacific. The influence of the QBO diminishes at lower isentropic levels near the Equator, but subtropical latitudes still seem to be affected by the phase of the QBO, with a non-significant tendency for decreasing temperatures and $\mathrm{H}_{2} \mathrm{O}$ mixing ratios above the TP at $360 \mathrm{~K}$. 


\section{Summary and conclusions}

The first part of this paper compares the ability of a number of CCMVal-2 CCMs to reproduce the climatological $\mathrm{H}_{2} \mathrm{O}$ and $\mathrm{O}_{3}$ distributions, the circulation patterns, and temperatures in the UTLS associated with the ASM with MIPAS $\mathrm{H}_{2} \mathrm{O}$ and $\mathrm{O}_{3}$ satellite observations and ERA-Interim reanalyses. The climatological $\mathrm{O}_{3}$ mixing ratios of the MMOD on isentropic surfaces (360-380 K) in the UTLS are in good agreement with MIPAS observations. There are, however, quite large differences with respect to the $\mathrm{H}_{2} \mathrm{O}$ mixing ratios, in particular a moist bias in high latitudes in the MMOD. Both tracers show considerable deviations of their extreme values within the AMA in the individual models; however, the relative $\mathrm{O}_{3}$ minimum and $\mathrm{H}_{2} \mathrm{O}$ maximum is captured by all models. Evident from the $\mathrm{H}_{2} \mathrm{O}$ mixing ratios on isentropic levels is also some missing confinement within the AMA in most models; instead, there is a strong north-eastward $\mathrm{H}_{2} \mathrm{O}$ transport on the isentropes.

The horizontal and meridional circulation patterns, related to the AMA, are slightly less pronounced in the CCMs compared to ERA-Interim, except for the meridional winds at the eastern flank of the AMA (see Figs. S1-S4 in the Supplement). The CCMs are warmer in tropical and subtropical latitudes during JA at the $360 \mathrm{~K}$ surface, compared to ERA-Interim, but get colder at 370 and $380 \mathrm{~K}$. However, CCMs show a weaker ASM-induced temperature anomaly than ERA-Interim. We have to stress that individual models deviate from this overall behaviour of the MMOD.

The second part of the paper identified factors influencing the interannual variability of temperatures, $\mathrm{H}_{2} \mathrm{O}$, and $\mathrm{O}_{3}$ in the UTLS. We performed a MLR analysis, including a derived MIDX, the Niño3.4 index, and the QBO. By definition, the MIDX is a measure of strength of the ASM in the upper troposphere at $150 \mathrm{hPa}$. Regressing the MIDX on ERA-Interim temperatures suggests for strong ASM seasons an upper-tropospheric warming south-east of the AMA and two separated areas of cooling, one in the western part of the AMA and one to the north-east of the AMA. Regressing the MIDX on NOAA OLR data indicates decreases of OLR over the Indian subcontinent, the southern part of the $\mathrm{BoB}$, the western coast of Myanmar, and Hanai during July and August, thus indicating an increase in deep convection south-east of the AMA core. Regions where MIDX correlates to OLR differences or temperature changes are largely dislocated. While the OLR differences reflect the areas of strongest convection in the ASM, the subtropical dipole of cooling with centres over Iran and north-eastern China reflects the dynamical response to the diabatic convective heating. The corresponding regression patterns for $\mathrm{H}_{2} \mathrm{O}$ and $\mathrm{O}_{3}$ mixing ratios emphasize the ability of strong ASM seasons to moisten the air within the AMA, whereas $\mathrm{O}_{3}$ mixing ratios tend to be lower. We get a colder tropopause region at the northern edge of the AMA and a warmer one at the southern edge with increasing MIDX. This warmer region is partly overlapping with a region above the southern TP that was identified by Bergman et al. (2013) as a region of preferred vertical transport. Hence, the difference to the study of Randel et al. (2015) is mainly based on the different representation of the ASM intensity.

The regressions of the MIDX on the temperatures of the CCMs indicate that the CCMs do not capture the warming to the south-east, as shown for the ERA-Interim temperatures. Instead UTLS temperatures at $360 \mathrm{~K}$ increase with monsoon intensity in the ASM region centred above the TP, which enhances the seasonal high climatological temperatures over the elevated TP. The anomalous warming coincides with increased $\mathrm{H}_{2} \mathrm{O}$ and decreased $\mathrm{O}_{3}$ mixing ratios. At 370 and $380 \mathrm{~K}$ increased $\mathrm{H}_{2} \mathrm{O}$ is still present above the TP but the region of increased $\mathrm{H}_{2} \mathrm{O}$ extends to the north-east, confirming the potential of the ASM in moistening the lowermost stratosphere at higher latitudes during boreal summer (e.g. Rosenlof et al., 1997; Dethof et al., 1999; Ploeger et al., 2013). The pattern of decreased $\mathrm{O}_{3}$ concentrations during strong ASM seasons is quite persistent on all three isentropic levels, which are located at the western and north-eastern edge of the AMA.

It is well known that ENSO and ASM strength are not independent; e.g. after an ENSO warm event the strength of the ASM is often reduced (Ju and Slingo, 1995). In our study some patterns of the regression coefficients of the Niño3.4 index mirror, as expected, the MIDX regression patterns near the Equator between $15^{\circ} \mathrm{S}$ and $15^{\circ} \mathrm{N}$, reflecting the shift of the most intense convection to the central Pacific during ENSO warm events. We note that the ENSO modulation of the ASM is non-negligible and that nonlinear interactions may exist that are likely to complicate the unambiguous detection of the MIDX signal.

The results from the regression of the QBO time series on temperature, $\mathrm{H}_{2} \mathrm{O}$, and $\mathrm{O}_{3}$ mixing ratios confirm the expected modulation of the transport in the UTLS by the QBOinduced MMC. The CCMs can reproduce the QBO-induced temperature anomalies on the $400 \mathrm{~K}$ isentropic surface, i.e. a warming near the Equator and cooling in the subtropics, as well as the $\mathrm{O}_{3}$ transport anomalies and to a certain degree the $\mathrm{H}_{2} \mathrm{O}$ anomalies that are related to the temperature changes.

The results of the CCMs during strong ASM seasons confirm the importance of the TP and the southern slope of the Himalayas for the $\mathrm{H}_{2} \mathrm{O}$ transport to the UTLS above the ASM region (e.g. Fu et al., 2006; Wright et al., 2011; Bergman et al., 2013). The coinciding positive temperature anomalies suggest transport of $\mathrm{H}_{2} \mathrm{O}$ through this region rather than transport through the southern flank of the AMA, where temperatures are lower during strong ASM seasons. Results from CCMs and reanalyses further indicate that $\mathrm{H}_{2} \mathrm{O}$ is transported towards higher latitudes on isentropic levels as suggested previously by Dethof et al. (1999) and Ploeger et al. (2013) rather than fed into the tropical UTLS to contribute to the $\mathrm{H}_{2} \mathrm{O}$ tape recorder seasonality, as proposed by 
other studies (e.g. Bannister et al., 2004; Gettelman et al., 2004).

\section{Data availability}

The CCM data used in this study are collected within the Chemistry-Climate Model Validation (CCMVal) Activity for WCRP's (World Climate Research Programme) SPARC (Stratospheric Processes and their Role in Climate) and are available from the CCMVal-II database at the British Atmospheric Data Centre: http://browse.ceda.ac.uk/browse/ badc/ccmval/data/CCMVal-2/Reference_Runs/REF-B1/ (British Atmospheric Data Centre, 2009). The European Centre for Medium-range Weather Forecasts (ECMWF) interim reanalyses (ERA-Interim) data (Dee et al., 2011) used in this study are available from the ECMWF: http:// apps.ecmwf.int/datasets/data/interim-full-moda/levtype $=\mathrm{ml} /$ (ECMWF, 2015). The Interpolated Outgoing Longwave Radiation (OLR) data (Liebmann and Smith, 1996) are available from the website of the National Oceanic \& Atmospheric Administration/Earth System Research Laboratory/Office of Oceanic and Atmospheric Research, Physical Sciences Division (NOAA/OAR/ESRL, PSD), Boulder, Colorado, USA: http://www.esrl.noaa.gov/psd/ data/gridded/data.interp_OLR.html (NOAA/OAR/ESRL, 2014). The HadISST1 data set (Rayner et al., 2003) is available from the UK Meteorological Office Hadley Centre: http: //www.metoffice.gov.uk/hadobs/hadisst/data/download.html (UK Meteorological Office Hadley Centre, 2014). The Michelson Interferometer for Passive Atmospheric Sounding (MIPAS) satellite data (Milz et al., 2009; von Clarmann et al., 2009; Steck et al., 2007) used in this study have been provided by the Karlsruhe Institute of Technology - Institute of Meteorology and Climate Research - Atmospheric Trace Gases and Remote Sensing (KIT-IKM-ASF) (S. Lossow, personal communication, 18 October 2013).

\section{The Supplement related to this article is available online at doi:10.5194/acp-16-8695-2016-supplement.}

Acknowledgements. We acknowledge the modelling groups for making their simulations available for this analysis, the ChemistryClimate Model Validation (CCMVal) Activity for WCRP's (World Climate Research Programme) SPARC (Stratospheric Processes and their Role in Climate) project for organizing and coordinating the model data analysis activity, and the British Atmospheric Data Centre (BADC) for collecting and archiving the CCMVal model output. European Centre for Medium-range Weather Forecasts (ECMWF) ERA-Interim data used in this study have been obtained from the ECMWF data server. Interpolated OLR data were provided by the NOAA/OAR/ESRL PSD, Boulder, Colorado, USA, from their website at http://www.esrl.noaa.gov/psd/. Markus Kunze was supported by the European Community within the StratoClim project (grant no. 603557).

Edited by: J. Ma

Reviewed by: three anonymous referees

\section{References}

Bannister, R. N., O’Neill, A., Gregory, A. R., and Nissen, K. M.: The role of the south-east Asian monsoon and other seasonal features in creating the "tape-recorder" signal in the Unified Model, Q. J. Roy. Meteor. Soc., 130, 1531-1554, doi:10.1256/qj.03.106, 2004.

Bergman, J. W., Fierli, F., Jensen, E. J., Honomichl, S., and Pan, L. L.: Boundary layer sources for the Asian anticyclone: Regional contributions to a vertical conduit, J. Geophys. Res.Atmos., 118, 2560-2575, doi:10.1002/jgrd.50142, 2013.

Bodeker, G. E., Boyd, I. S., and Matthews, W. A.: Trends and variability in vertical ozone and temperature profiles measured by ozonesondes at Lauder, New Zealand: 1986-1996, J. Geophys. Res.-Atmos., 103, 28661-28681, doi:10.1029/98JD02581, 1998.

Boos, W. R. and Kuang, Z.: Dominant control of the South Asian monsoon by orographic insulation versus plateau heating, Nature, 463, 218-222, doi:10.1038/nature08707, 2010.

Braesicke, P., Smith, O. J., Telford, P., and Pyle, J. A.: Ozone concentration changes in the Asian summer monsoon anticyclone and lower stratospheric water vapour: An idealised model study, Geophys. Res. Lett., 38, L03810, doi:10.1029/2010GL046228, 2011.

Brewer, A. W.: Evidence for a world circulation provided by the measurements of helium and water vapour distribution in the stratosphere, Q. J. Roy. Meteor. Soc., 75, 351-363, 1949.

British Atmospheric Data Centre: CCMVal-II database, ChemistryClimate Model Validation (CCMVal) Activity for WCRP's (World Climate Research Programme) SPARC (Stratospheric Processes and their Role in Climate), available at (login required): http://browse.ceda.ac.uk/browse/badc/ccmval/data/ CCMVal-2/Reference_Runs/REF-B1/, last access: 7 April 2009.

Chen, B., Xu, X. D., Yang, S., and Zhao, T. L.: Climatological perspectives of air transport from atmospheric boundary layer to tropopause layer over Asian monsoon regions during boreal summer inferred from Lagrangian approach, Atmos. Chem. Phys., 12, 5827-5839, doi:10.5194/acp-12-5827-2012, 2012.

Cordero, E. C., Kawa, S. R., and Schoeberl, M. R.: An analysis of tropical transport: Influence of the quasi-biennial oscillation, J. Geophys. Res.-Atmos., 102, 16453-16461, doi:10.1029/97JD01053, 1997.

Corti, T., Luo, B. P., de Reus, M., Brunner, D., Cairo, F., Mahoney, M. J., Martucci, G., Matthey, R., Mitev, V., dos Santos, F. H., Schiller, C., Shur, G., Sitnikov, N. M., Spelten, N., Vössing, H. J., Borrmann, S., and Peter, T.: Unprecedented evidence for deep convection hydrating the tropical stratosphere, Geophys. Res. Lett., 35, L10810, doi:10.1029/2008GL033641, 2008.

Dee, D. P., Uppala, S. M., Simmons, A. J., Berrisford, P., Poli, P., Kobayashi, S., Andrae, U., Balmaseda, M. A., Balsamo, G., Bauer, P., Bechtold, P., Beljaars, A. C. M., van de Berg, L., Bidlot, J., Bormann, N., Delsol, C., Dragani, R., Fuentes, M., Geer, A. J., Haimberger, L., Healy, S. B., Hersbach, H., Hólm, E. V., 
Isaksen, L., Kållberg, P., Köhler, M., Matricardi, M., McNally, A. P., Monge-Sanz, B. M., Morcrette, J.-J., Park, B.-K., Peubey, C., de Rosnay, P., Tavolato, C., Thépaut, J.-N., and Vitart, F.: The ERA-Interim reanalysis: configuration and performance of the data assimilation system, Q. J. Roy. Meteor. Soc., 137, 553-597, doi:10.1002/qj.828, 2011.

Dethof, A., O’Neill, A., Slingo, J. M., and Schmit, H. G. J.: A mechanism for moistening the lower stratosphere involving the Asian summer monsoon, Q. J. Roy. Meteor. Soc., 125, 10791106, 1999.

Dragani, R.: On the quality of the ERA-Interim ozone reanalyses: comparisons with satellite data, Q. J. Roy. Meteor. Soc., 137, 1312-1326, doi:10.1002/qj.821, 2011.

European Centre for Medium-range Weather Forecasts (ECMWF): ERA-Interim data, available at: http://apps.ecmwf.int/datasets/ data/interim-full- moda/levtype $=\mathrm{ml} /$, last access: 19 September 2015.

Eyring, V., Chipperfiel, M. P., Giorgetta, M. A., Kinnison, D., Manzini, E., Matthes, K., Newman, P. A., Pawson, S., Shepherd, T. G., and Waugh, D. W.: Overview of the New CCMVal Reference and Sensitivity Simulations in Support of Upcoming Ozone and Climate Assessments and the Planned SPARC CCMVal Report, SPARC newsletter, 30, 20-26, 2008.

Fu, R., Hu, Y., Wright, J. S., Jiang, J. H., Dickinson, R. E., Chen, M., Filipiak, M., Read, W. G., Waters, J. W., and Wu, D. L.: Short circuit of water vapor and polluted air to the global stratosphere by convective transport over the Tibetan Plateau, P. Natl. Acad. Sci. USA, 103, 5664-5669, doi:10.1073/pnas.0601584103, 2006.

Fueglistaler, S., Wernli, H., and Peter, T.: Tropical troposphereto-stratosphere transport inferred from trajectory calculations, J. Geophys. Res.-Atmos., 109, D03108, doi:10.1029/2003JD004069, 2004.

Fueglistaler, S., Dessler, A. E., Dunkerton, T. J., Folkins, I., Fu, Q., and Mote, P. W.: Tropical tropopause layer, Rev. Geophys., 47, RG1004, doi:10.1029/2008RG000267, 2009.

Garny, H. and Randel, W. J.: Dynamic variability of the Asian monsoon anticyclone observed in potential vorticity and correlations with tracer distributions, J. Geophys. Res.-Atmos., 118, 1342113433, doi:10.1002/2013JD020908, 2013.

Gettelman, A., Randel, W. J., Massie, S., Wu, F., Read, W. G., and Russell, J. M.: El Niño as a Natural Experiment for Studying the Tropical Tropopause Region, J. Climate, 14, 3375-3392, doi:10.1175/1520-0442(2001)014<3375:ENOAAN>2.0.CO;2, 2001.

Gettelman, A., Kinnison, D. E., Dunkerton, T. J., and Brasseur, G.: Impact of monsoon circulations on the upper troposphere and lower stratosphere, J. Geophys. Res., 109, D22101, doi:10.1029/2004JD004878, 2004.

Gill, A. E.: Some simple solutions for heat-induced tropical circulation, Q. J. Roy. Meteor. Soc., 106, 447-462, doi:10.1002/qj.49710644905, 1980.

Giorgetta, M. A. and Bengtsson, L.: Potential role of the quasi-biennial oscillation in the stratosphere-troposphere exchange as found in water vapor in general circulation model experiments, J. Geophys. Res.-Atmos., 104, 6003-6019, doi:10.1029/1998JD200112, 1999.

Giorgetta, M. A., Bengtsson, L., and Arpe, K.: An investigation of QBO signals in the east Asian and Indian mon- soon in GCM experiments, Clim. Dynam., 15, 435-450, doi:10.1007/s003820050292, 1999.

Goswami, B. N., Krishnamurthy, V., and Annamalai, H.: A broadscale circulation index for the interannual variability of the Indian summer monsoon, Q. J. Roy. Meteor. Soc., 125, 611-633, 1999.

Heath, N. K. and Fuelberg, H. E.: Using a WRF simulation to examine regions where convection impacts the Asian summer monsoon anticyclone, Atmos. Chem. Phys., 14, 2055-2070, doi:10.5194/acp-14-2055-2014, 2014.

Holton, J. R. and Gettelman, A.: Horizontal transport and the dehydration of the stratosphere, Geophys. Res. Lett., 28, 2799-2802, doi:10.1029/2001GL013148, 2001.

IPCC: Climate Change 2001: The Scientific Basis, in: Third Assessment Report of the Intergovernmental Panel on Climate Change, edited by: Houghton, J. T., Ding, Y., Griggs, D., Griggs, D., van der Linden, P., Dai, X., Maskell, K., and Johnson, C., p. 881, Cambridge University Press, Cambridge, UK and New York, USA, 2001.

James, R., Bonazzola, M., Legras, B., Surbled, K., and Fueglistaler, S.: Water vapor transport and dehydration above convective outflow during Asian monsoon, Geophys. Res. Lett., 35, L20810, doi:10.1029/2008GL035441, 2008.

Jensen, E. and Pfister, L.: Transport and freeze-drying in the tropical tropopause layer, J. Geophys. Res.-Atmos., 109, D02207, doi:10.1029/2003JD004022, 2004.

$\mathrm{Ju}$, J. and Slingo, J.: The Asian summer monsoon and ENSO, Q. J. Roy. Meteor. Soc., 121, 1133-1168, doi:10.1002/qj.49712152509, 1995.

Konopka, P., Grooß, J.-U., Plöger, F., and Müller, R.: Annual cycle of horizontal in-mixing into the lower tropical stratosphere, J. Geophys. Res.-Atmos., 114, D19111, doi:10.1029/2009JD011955, 2009.

Konopka, P., Grooß, J.-U., Günther, G., Ploeger, F., Pommrich, R., Müller, R., and Livesey, N.: Annual cycle of ozone at and above the tropical tropopause: observations versus simulations with the Chemical Lagrangian Model of the Stratosphere (CLaMS), Atmos. Chem. Phys., 10, 121-132, doi:10.5194/acp-10-121-2010, 2010.

Kremser, S., Wohltmann, I., Rex, M., Langematz, U., Dameris, M., and Kunze, M.: Water vapour transport in the tropical tropopause region in coupled Chemistry-Climate Models and ERA-40 reanalysis data, Atmos. Chem. Phys., 9, 2679-2694, doi:10.5194/acp-9-2679-2009, 2009.

Kunze, M., Braesicke, P., Langematz, U., Stiller, G., Bekki, S., Brühl, C., Chipperfield, M., Dameris, M., Garcia, R., and Giorgetta, M.: Influences of the Indian summer monsoon on water vapor and ozone concentrations in the UTLS as simulated by Chemistry-Climate models, J. Climate, 23, 3525-3544, doi:10.1175/2010JCLI3280.1, 2010.

Lean, J., Rottman, G., Harder, J., and Kopp, G.: SORCE Contributions to New Understanding of Global Change and Solar Variability, in: The Solar Radiation and Climate Experiment (SORCE), edited by: Rottman, G., Woods, T., and George, V., Springer New York, USA, 27-53, doi:10.1007/0-387-376259_3, 2005 .

Liebmann, B. and Smith, C.: Description of a Complete (Interpolated) Outgoing Longwave Radiation Dataset, B. Am. Meteorol Soc., 77, 1275-1277, 1996. 
Liu, Y., Hoskins, B., and Blackburn, M.: Impact of Tibetan Orography and Heating on the Summer Flow over Asia, J. Meteorol. Soc. Jpn. Ser. II, 85B, 1-19, doi:10.2151/jmsj.85B.1, 2007.

Logan, J. A., Jones, D. B. A., Megretskaia, I. A., Oltmans, S. J., Johnson, B. J., Vömel, H., Randel, W. J., Kimani, W., and Schmidlin, F. J.: Quasibiennial oscillation in tropical ozone as revealed by ozonesonde and satellite data, J. Geophys. Res.Atmos., 108, 4244, doi:10.1029/2002JD002170, 2003.

Milz, M., Clarmann, T. v., Bernath, P., Boone, C., Buehler, S. A., Chauhan, S., Deuber, B., Feist, D. G., Funke, B., Glatthor, N., Grabowski, U., Griesfeller, A., Haefele, A., Höpfner, M., Kämpfer, N., Kellmann, S., Linden, A., Müller, S., Nakajima, H., Oelhaf, H., Remsberg, E., Rohs, S., Russell III, J. M., Schiller, C., Stiller, G. P., Sugita, T., Tanaka, T., Vömel, H., Walker, K., Wetzel, G., Yokota, T., Yushkov, V., and Zhang, G.: Validation of water vapour profiles (version 13) retrieved by the IMK/IAA scientific retrieval processor based on full resolution spectra measured by MIPAS on board Envisat, Atmos. Meas. Tech., 2, 379-399, doi:10.5194/amt-2-379-2009, 2009.

Mitchell, D. M., Gray, L. J., Fujiwara, M., Hibino, T., Anstey, J. A., Ebisuzaki, W., Harada, Y., Long, C., Misios, S., Stott, P. A., and Tan, D.: Signatures of naturally induced variability in the atmosphere using multiple reanalysis datasets, Q. J. Roy. Meteor. Soc., 141, 2011-2031, doi:10.1002/qj.2492, 2014.

Morgenstern, O., Giorgetta, M. A., Shibata, K., Eyring, V., Waugh, D. W., Shepherd, T. G., Akiyoshi, H., Austin, J., Baumgaertner, A. J. G., Bekki, S., Braesicke, P., Brühl, C., Chipperfield, M. P., Cugnet, D., Dameris, M., Dhomse, S., Frith, S. M., Garny, H., Gettelman, A., Hardiman, S. C., Hegglin, M. I., Jöckel, P., Kinnison, D. E., Lamarque, J.-F., Mancini, E., Manzini, E., Marchand, M., Michou, M., Nakamura, T., Nielsen, J. E., Olivié, D., Pitari, G., Plummer, D. A., Rozanov, E., Scinocca, J. F., Smale, D., Teyssèdre, H., Toohey, M., Tian, W., and Yamashita, Y.: Review of the formulation of present-generation stratospheric chemistryclimate models and associated external forcings, J. Geophys. Res.-Atmos., 115, D00M02, doi:10.1029/2009JD013728, 2010.

National Oceanic \& Atmospheric Administration/Earth System Research Laboratory/Office of Oceanic and Atmospheric Research (NOAA/OAR/ESRL): Interpolated Outgoing Longwave Radiation (OLR) data, Physical Sciences Division, Boulder, Colorado, USA, available at: http://www.esrl.noaa.gov/psd/data/gridded/ data.interp_OLR.html, last access: 17 October 2014.

Pan, L., Solomon, S., Randel, W., Lamarque, J.-F., Hess, P., Gille, J., Chiou, E.-W., and McCormick, M. P.: Hemispheric asymmetries and seasonal variations of the lowermost stratospheric water vapor and ozone derived from SAGE II data, J. Geophys. Res., 102, 28177-28184, doi:10.1029/97JD02778, 1997.

Park, M., Randel, W. J., Gettelman, A., Massie, S. T., and Jiang, J. H.: Transport above the Asian summer monsoon anticyclone inferred from Aura Microwave Limb Sounder tracers, J. Geophys. Res., 112, D16309, doi:10.1029/2006JD008294, 2007.

Park, M., Randel, W. J., Emmons, L. K., and Livesey, N. J.: Transport pathways of carbon monoxide in the Asian summer monsoon diagnosed from Model of Ozone and Related Tracers (MOZART), J. Geophys. Res., 114, D08303, doi:10.1029/2008JD010621, 2009.

Ploeger, F., Fueglistaler, S., Grooß, J.-U., Günther, G., Konopka, P., Liu, Y. S., Müller, R., Ravegnani, F., Schiller, C., Ulanovski, A., and Riese, M.: Insight from ozone and water vapour on transport in the tropical tropopause layer (TTL), Atmos. Chem. Phys., 11, 407-419, doi:10.5194/acp-11-407-2011, 2011.

Ploeger, F., Konopka, P., Müller, R., Fueglistaler, S., Schmidt, T., Manners, J. C., Grooß, J.-U., Günther, G., Forster, P. M., and Riese, M.: Horizontal transport affecting trace gas seasonality in the Tropical Tropopause Layer (TTL), J. Geophys. Res.-Atmos., 117, D09303, doi:10.1029/2011JD017267, 2012.

Ploeger, F., Günther, G., Konopka, P., Fueglistaler, S., Müller, R., Hoppe, C., Kunz, A., Spang, R., Grooß, J.-U., and Riese, M.: Horizontal water vapor transport in the lower stratosphere from subtropics to high latitudes during boreal summer, J. Geophys Res.-Atmos., 118, 8111-8127, doi:10.1002/jgrd.50636, 2013.

Plumb, R. A. and Bell, R. C.: A model of the quasi-biennial oscillation on an equatorial beta-plane, Q. J. Roy. Meteor. Soc., 108, 335-352, doi:10.1002/qj.49710845604, 1982.

Randel, W. J. and Park, M.: Deep convective influence on the Asian summer monsoon anticyclone and associated tracer variability observed with Atmospheric Infrared Sounder (AIRS), J. Geophys. Res., 111, D12314, doi:10.1029/2005JD006490, 2006.

Randel, W. J., Wu, F., and Gaffen, D. J.: Interannual variability of the tropical tropopause derived from radiosonde data and NCEP reanalyses, J. Geophys. Res.-Atmos., 105, 15509-15523, doi:10.1029/2000JD900155, 2000.

Randel, W. J., Park, M., Emmons, L., Kinnison, D., Bernath, P., Walker, K. A., Boone, C., and Pumphrey, H.: Asian Monsoon Transport of Pollution to the Stratosphere, Science, 328, 611613, doi:10.1126/science.1182274, 2010.

Randel, W. J., Zhang, K., and Fu, R.: What controls stratospheric water vapor in the NH summer monsoon regions?, J. Geophys. Res.-Atmos., 120, 7988-8001, doi:10.1002/2015JD023622, 2015.

Rayner, N. A., Parker, D. E., Horton, E. B., Folland, C. K., Alexander, L. V., Rowell, D. P., Kent, E. C., and Kaplan, A.: Global analyses of sea surface temperature, sea ice, and night marine air temperature since the late nineteenth century, J. Geophys. Res.Atmos., 108, 4407, doi:10.1029/2002JD002670, 2003.

Rosenlof, K. H., Tuck, A. F., Kelly, K. K., Russell, J. M., and McCormick, M. P.: Hemispheric asymmetries in water vapor and inferences about transport in the lower stratosphere, J. Geophys. Res., 102, 13213-13234, doi:10.1029/97JD00873, 1997.

Sherwood, S. C. and Dessler, A. E.: On the control of stratospheric humidity, Geophys. Res. Lett., 27, 2513-2516, doi:10.1029/2000GL011438, 2000.

SPARC CCMVal: SPARC CCMVal Report on the Evaluation of Chemistry-Climate Models, edited by: Eyring, V., Shepherd, T., and Waugh, D., SPARC Report No. 5, WCRP-132, WMO/TDNo. 1526, 2010.

Steck, T., von Clarmann, T., Fischer, H., Funke, B., Glatthor, N., Grabowski, U., Höpfner, M., Kellmann, S., Kiefer, M., Linden, A., Milz, M., Stiller, G. P., Wang, D. Y., Allaart, M., Blumenstock, Th., von der Gathen, P., Hansen, G., Hase, F., Hochschild, G., Kopp, G., Kyrö, E., Oelhaf, H., Raffalski, U., Redondas Marrero, A., Remsberg, E., Russell III, J., Stebel, K., Steinbrecht, W., Wetzel, G., Yela, M., and Zhang, G.: Bias determination and precision validation of ozone profiles from MIPAS-Envisat retrieved with the IMK-IAA processor, Atmos. Chem. Phys., 7, 3639-3662, doi:10.5194/acp-7-3639-2007, 2007. 
Stouffer, S., Suchman, E., DeVinney, L., Star, S., and Williams, R. J.: The American Soldier: Adjustment during Army Life, Volume I, Princeton University Press, Princeton, N.J., USA, 1949.

Tanaka, H. L., Ishizaki, N., and Kitoh, A.: Trend and interannual variability of Walker, monsoon and Hadley circulations defined by velocity potential in the upper troposphere, Tellus A, 56, 250269, doi:10.3402/tellusa.v56i3.14410, 2004.

Tiao, G. C., Reinsel, G. C., Xu, D., Pedrick, J. H., Zhu, X., Miller, A. J., DeLuisi, J. J., Mateer, C. L., and Wuebbles, D. J.: Effects of autocorrelation and temporal sampling schemes on estimates of trend and spatial correlation, J. Geophys. Res.-Atmos., 95, 20507-20517, doi:10.1029/JD095iD12p20507, 1990.

UK Meteorological Office Hadley Centre: HadISST1 data set, available at: http://www.metoffice.gov.uk/hadobs/hadisst/data/ download.html, last access: 17 November 2014.

Uppala, S. M., Kallberg, P. W., Simmons, A. J., Andrae, U., da Costa Bechtold, V., Fiorino, M., Gibson, J. K., Haseler, J., Hernandez, A., Kelly, G. A., Li, X., Onogi, K., Saarinen, S., Sokka, N., Allan, R. P., Andersson, E., Arpe, K., Balmaseda, M. A., Beljaars, A. C. M., van de Berg, L., Bidlot, J., Bormann, N., Caires, S., Chevallier, F., Dethof, A., Dragosavac, M., Fisher, M., Fuentes, M., Hagemann, S., Hólm, E., Hoskins, B. J., Isaksen, L., Janssen, P. A. E. M., Jenne, R., McNally, A. P., Mahfouf, J.-F., Morcrette, J.-J., Rayner, N. A., Saunders, R. W., Simon, P., Sterl, A., Trenberth, K. E., Untch, A., Vasiljevic, D., Viterbo, P., and Woollen, J.: The ERA-40 re-analysis, Q. J. Roy. Meteor. Soc., 131, 2961-3012, doi:10.1256/qj.04.176, 2005.

van Loon, H. and Meehl, G. A.: The Indian summer monsoon during peaks in the 11 year sunspot cycle, Geophys. Res. Lett., 39, L13701, doi:10.1029/2012GL051977, 2012.

von Clarmann, T., Höpfner, M., Funke, B., López-Puertas, M., Dudhia, A., Jay, V., Schreier, F., Ridolfi, M., Ceccherini, S., Kerridge, B. J., Reburn, J., and Siddans, R.: Modelling of atmospheric mid-infrared radiative transfer: the AMIL2DA algorithm intercomparison experiment, J. Quant. Spectrosc. Ra., 78, 381-407, doi:10.1016/S0022-4073(02)00262-5, 2003. von Clarmann, T., Höpfner, M., Kellmann, S., Linden, A., Chauhan, S., Funke, B., Grabowski, U., Glatthor, N., Kiefer, M., Schieferdecker, T., Stiller, G. P., and Versick, S.: Retrieval of temperature, $\mathrm{H}_{2} \mathrm{O}, \mathrm{O}_{3}, \mathrm{HNO}_{3}, \mathrm{CH}_{4}, \mathrm{~N}_{2} \mathrm{O}, \mathrm{ClONO}_{2}$ and $\mathrm{ClO}$ from MIPAS reduced resolution nominal mode limb emission measurements, Atmos. Meas. Tech., 2, 159-175, doi:10.5194/amt-2-159-2009, 2009.

Webster, P. J. and Yang, S.: Monsoon and ENSO: Selectively interactive systems, Q. J. Roy. Meteor. Soc., 118, 877-926, 1992.

Webster, P. J., Magaña, V. O., Palmer, T. N., Shukla, J., Tomas, R. A., Yanai, M., and Yasunari, T.: Monsoons: Processes, predictability, and the prospects for prediction, J. Geophys. Res.Oceans, 103, 14451-14510, doi:10.1029/97JC02719, 1998.

Whitlock, M.: Combining probability from independent tests: the weighted $Z$ method is superior to Fisher's approach, J. Evolution. Biol., 18, 1368-1373, doi:10.1111/j.1420-9101.2005.00917.x, 2005.

WMO: Scientific assessment of ozone depletion: 2006, Ozone Res. Monit. Proj. Rep. No. 50, 572 pp., Geneva, Switzerland, 2007.

Wright, J. S., Fu, R., Fueglistaler, S., Liu, Y. S., and Zhang, Y.: The influence of summertime convection over Southeast Asia on water vapor in the tropical stratosphere, J. Geophys. Res.-Atmos., 116, D12302, doi:10.1029/2010JD015416, 2011.

Yang, S., Webster, P., and Min, D.: Longitudinal heating gradient: Another possible factor influencing the intensity of the Asian summer monsoon circulation, Adv. Atmos. Sci., 9, 397-410, doi:10.1007/BF02677073, 1992.

Zhou, X.-L., Geller, M. A., and Zhang, M.: Cooling trend of the tropical cold point tropopause temperatures and its implications, J. Geophys. Res.-Atmos., 106, 1511-1522, doi:10.1029/2000JD900472, 2001. 